\title{
5 Research Square

\section{Bibliometric analysis in databases on publications related to the replacement of natural aggregates by residues with a focus on sustainability and Brazil}

Carlos Alberto de Albuquerque ( $\nabla$ carlos.albuquerque@ifsuldeminas.edu.br)

Instituto Federal de Educação Ciência e Tecnologia do Sul de Minas Gerais https://orcid.org/00000001-5187-3643

\section{Carlos Henrique Pereira Mello}

Federal University of Itajubá: Universidade Federal de Itajuba

José Henrique de Freitas Gomes

Federal University of Itajubá: Universidade Federal de Itajuba

Valquíria Claret dos Santos

Federal University of Itajubá: Universidade Federal de Itajuba

\section{Research Article}

Keywords: Brazil, waste, concrete, aggregate, residue, sustainability

Posted Date: February 12th, 2021

DOI: https://doi.org/10.21203/rs.3.rs-220203/v1

License: (9) This work is licensed under a Creative Commons Attribution 4.0 International License.

Read Full License 


\section{Abstract}

As part of a research project on the substitution of natural aggregates for residues, this article carried out a literature review, identifying articles that have the words aggregates, residues and concrete in their topics, in the Scopus and Web of Sciences bases. Among the main objectives of this review are: to verify what is the relative position of Brazil in relation to research in the area of substitution of aggregate for waste; to identify the main residues that are being studied to be used as raw material substitutes in the construction industry, mainly in Brazil; evaluate the hypothesis that a search using the words concrete, aggregate and residue will result in articles from the environmental and civil engineering areas. The main results are: Brazil is the country that most published articles with the characteristics investigated in the present work, followed by the countries China, Italy, USA and Spain; articles by Brazilian authors are predominantly from the areas of engineering and the environment; there are several studies investigating the substitution of natural aggregates for residues, mainly the substitution for residues of the civil construction itself; in Brazil, the most investigated residues to be used as raw material substitutes for the civil engineering industry are the residues of the civil engineering industry and the residues of agricultural products. The result of the review also identified the need for an improvement in the data and research tools of the databases used. The reasons are the probable data inconsistencies and flaws in the research tools found in the databases. With all these results, this work intends to provide basic information for researchers who intend to initiate research on the substitution of natural aggregates for waste, in addition to using them to continue the research project of replacing part of natural aggregates with electronic waste in the production of concrete. It also intends to show the importance of revision work for the improvement of data and database tools.

\section{Introduction}

Various actions, such as the increase in the number of Universities and Institutes with a focus on sustainability, contribute to infer that the commitment to sustainability is growing in the world (Khalili et al., 2015). This increase has produced improvements in some environmental indicators in recent decades. However, empirical data shows that the global increase in energy and raw material consumption has put pressure on the environment (Askham et al., 2012), mainly due to the exponential increase in the exploitation of natural resources observed in the last decades. (Gómez-Baggethun \& Naredo, 2015). Along with the increase in the consumption of natural resources, the generation of waste is also a negative factor for sustainable development. Thus, the use of waste as a raw material contributes to sustainable development, since this practice has the main benefits of reducing environmental pollution and conserving natural resources (Onuaguluchi \& Panesar, 2014).

The construction industry is largely responsible for extracting resources from nature, and today it is the largest consumer of limited natural resources, including sand, water, rocks and gravel (Mefteh et al., 2013). Many natural aggregates used in concrete are dug out of maritime mats, riverbeds, mines and other natural geological structures (Khankhaje et al., 2016). These activities cause irreparable damage to 
the environment due to the destruction of the geological structure and the contamination of the soil, air and water (Khankhaje et al., 2017).

In view of what has been exposed so far, this work understands that a way to contribute to lessen the negative impacts to nature, caused by the construction industry, is to replace part of the natural aggregates with residues in the production of concrete. As an initial step in this project, a literature review was carried out, with the following objectives:

- Identify the profile of the articles with the words aggregates, residues and concrete in the title, abstract or keywords, in the Scopus and Web of Science databases and with Brazilian authors; and

- Obtain basic information on the types of waste under investigation to replace natural aggregates, mainly in Brazil.

When obtaining this information from the literature review, this present work intends to provide basic information for researchers who intend to initiate research on the substitution of natural aggregates for residues. Another objective is to use this data to continue this project, investigating the use of electronic waste as a substitute for part of natural aggregates in the production of concrete.

In the course of this research, possible inconsistencies in the data and results provided by the tools used were identified. When identifying these possible inconsistencies, the objective of this work also became to contribute to the improvement of the information provided by the databases used, in addition to demonstrating the importance of literature review works to give the bases reliability and correct any information errors.

\section{Methodology}

On 09/30/2020 a survey was carried out on the Scopus base. In this research, articles were selected that had the words aggregates, residues and concrete in the title or keywords, or in the abstract. The same process was carried out on the Web of Sciences database, on 10/07/2020. With the research data, graphics were produced that shows the distribution of articles by year of publication, by country and by subject area.

After analyzing the results of the information obtained so far, this work quantitatively analyzed the data related to articles in the environmental areas. The reason is that these are the areas of interest of this present work. These analyzes produced graphs showing the distribution of articles by year of publication and country of the authors.

As one of the objectives of this work is to identify the profile of these articles with Brazilian authors, graphics were produced that presented the following data: distribution by year of publication; distribution by thematic area; distribution, by year of publication, of articles with Brazilian authors in the environmental area; types of waste studied; graphics showing the occurrence of the words investigated 
here in the title, abstract or keywords; and finally, a table with the most relevant information from the articles analyzed here.

\section{Results}

\subsection{Scopus Base}

In the Scopus database, 371 articles were identified containing the words aggregates, residues and concrete in the title or in the keywords or in the abstract. Figure 1 shows the distribution, by year of publication, of these articles.

Figure 2 shows the 20 countries that most published articles with the words aggregates, residues and concrete in the title or in the keywords or in the abstract. It is worth mentioning that the Scopus Base was unable to identify the country of origin of 41 articles.

Figure 3 shows the distribution of the 371 articles in the Scopus database by subject area.

Figure 4 shows the distribution, by country, of the 99 articles found in the Scopus database that have the words aggregates, residues, concrete in the title or in the keywords or in the abstract and which are from the Environmental Science subject area.

Figure 5 shows the evolution of the number of publications of articles in the Environmental Science subject area in the Scopus database.

Figure 6 shows the summary of the main information for the article data in the Scopus database.

\subsubsection{Data about articles with Brazilian authors}

Figure 7 shows the distribution, per year, of Brazilian publications with the words aggregates, residues and concrete in the title or abstract or in the keywords.

Figure 8 shows the distribution of articles by Brazilian authors by subject area.

Figure 9 shows the number of articles, published per year, by Brazilian authors in the Environmental Science in the Scopus database.

Figure 10 shows the summary of the main information for the article data with Brazilian authors in the Scopus database.

\subsection{Web of Science Base}

Figure 11 shows the distribution, by year of publication, of articles with the words aggregates, residues and concrete in the title or in the keywords or in the abstract, in the Web of Science database. 
Figure 12 shows the distribution, by subject area, of the articles identified in the Web of Science database with the same characteristics as the articles researched in the Scopus database.

Figure 13 shows the number of publications, distributed by country in the Web of Science database.

Figure 14 shows the distribution, by year of publication, of articles in the Science Ecology Environmental subject area.

Figure 15 shows the distribution, by country, of articles in the Environmental Science area.

Figure 16 shows the summary of the main information for the article data on the Web of Sciences.

\subsubsection{Data about articles with Brazilian authors}

Figure 17 shows the distribution, by subject area, of articles that have the words aggregates, residues and concrete in the title or keywords or in the abstract in the Web of Science database.

Figure 18 shows the distribution, by year of publication, of articles that have Brazilian authors.

Figure 19 shows the distribution, by year of publication, of articles by Brazilian authors in the subject area Sciences Ecology Environmental.

Figure 20 shows the summary of the main information for article data with Brazilian authors in the Web of Sciences database.

\subsection{Environmental articles with Brazilian authors}

Chart 1 shows the main information from articles in the environmental areas with Brazilian authors. As can be seen in Chart 1 , the total number of articles identified was 35 . This quantity is different from the sum of the articles identified in the Web of Science database, which was 33, with the number of articles identified in the Scopus database, which was 8 . This is due to the fact that five articles are in the two bases. 
Frame 1: Main information of articles with Brazilian authors

\begin{tabular}{|c|c|c|c|c|}
\hline \multicolumn{3}{|l|}{ Article } & Journal & Methodology \\
\hline \multicolumn{3}{|c|}{ (Coppio et al., 2019) } & $\begin{array}{l}\text { Construction and Building } \\
\text { Materials }\end{array}$ & Experimental Research \\
\hline \multicolumn{3}{|c|}{$\begin{array}{l}\text { Words aggregate, residue and } \\
\text { concrete }\end{array}$} & objectives & $\begin{array}{l}\text { Main Conclusions or } \\
\text { Proposals }\end{array}$ \\
\hline Title & Abstract & Keywords & & \\
\hline $\begin{array}{l}\text { concrete, } \\
\text { aggregate, } \\
\text { wast }\end{array}$ & $\begin{array}{l}\text { concrete, } \\
\text { aggregate, } \\
\text { waste }\end{array}$ & Concrete & $\begin{array}{l}\text { To study the effects of } \\
\text { using foundry sand as a } \\
\text { fine aggregate of the } \\
\text { concrete mixture on the } \\
\text { compressive strength and } \\
\text { surface electrical resistivity. }\end{array}$ & $\begin{array}{l}\text { Compressive strength tends } \\
\text { to decrease with the use of } \\
\text { residual casting sand as a } \\
\text { fine aggregate. }\end{array}$ \\
\hline \multicolumn{3}{|l|}{ Article } & Journal & Methodology \\
\hline \multicolumn{3}{|c|}{ (Rangel et al., 2019) } & $\begin{array}{l}\text { Journal of Cleaner } \\
\text { Production }\end{array}$ & case study \\
\hline \multicolumn{3}{|c|}{$\begin{array}{l}\text { Words aggregate, residue and } \\
\text { concrete }\end{array}$} & objectives & $\begin{array}{l}\text { Main Conclusions or } \\
\text { Proposals }\end{array}$ \\
\hline
\end{tabular}

Title Abstract Keywords

\begin{tabular}{|c|c|c|c|c|}
\hline $\begin{array}{l}\text { concrete, } \\
\text { aggregate, }\end{array}$ & $\begin{array}{l}\text { concrete, } \\
\text { aggregate, } \\
\text { waste }\end{array}$ & $\begin{array}{l}\text { concrete, } \\
\text { aggregate, } \\
\text { waste }\end{array}$ & $\begin{array}{l}\text { To find a possible } \\
\text { relationship between the } \\
\text { origin of the waste and the } \\
\text { characteristics of the } \\
\text { resulting recycled } \\
\text { aggregate concrete. }\end{array}$ & $\begin{array}{l}\text { Using the waste } \\
\text { classification proposed in } \\
\text { the work can promote the } \\
\text { complete reuse of waste in } \\
\text { different cement products. }\end{array}$ \\
\hline
\end{tabular}

\section{Article}

(dos Anjos et al., 2017)

Words aggregate, residue and concrete

$\begin{array}{lll}\text { Title } & \text { Abstract } & \text { Keywords } \\ \begin{array}{lll}\text { concrete, } \\ \text { aggregate, }\end{array} & \begin{array}{l}\text { concrete, } \\ \text { aggregate, } \\ \text { residue }\end{array} & \text { concrete, } \\ & \text { waste }\end{array}$

Article

Journal

\section{Methodology}

Experimental Research

Management

objectives

Main Conclusions or

Proposals
Evaluate the effects of total and partial replacement of fine aggregate with blasted copper slag and abrasive blasting residue on Portland cement structural concrete.
Despite the tensile strength of the concrete decreased with the increase of the sandblasted copper slag content, the work concludes that total or partial replacement of the natural fine aggregates by this residue may be viable. 
(Amorim Júnior et al., 2018)

Words aggregate, residue and concrete
Title Abstract Keywords

concrete, concrete, aggregate, Check the influence of the aggregate, aggregate, residue recycled aggregate on the durability of the concrete subjected to the freezing and thawing cycles.
Experimental Research Materials

objectives

Main Conclusions or Proposals
The use of recycled aggregates proved to be efficient as a possible alternative to the incorporation of air in the concretes, presenting a durability factor at the end of the cycle higher than that presented by the reference mixture.

\section{Article}

(Lima \& Iwakiri, 2014)

Palavras aggregate, residue and concrete

Title Abstract Keywords

concrete, concrete, concrete, To evaluate the substitution aggregate, aggregate, aggregate, of fine aggregate for waste residue residue
Journal

Ciência Florestal

Objectives
Pinus spp in the production of structural masonry blocks.

\section{Methodology}

Experimental Research

Main Conclusions or Proposals
Satisfactory results were obtained by replacing up to $50 \%$ of the mineral fine aggregate with the Pinus spp.

\section{Article}

(da Silva et al., 2020)

Palavras aggregate, residue and concrete
Journal

Waste Management \& Research

objectives

\section{Methodology}

Experimental Research

Main Conclusions or Proposals aggregate aggregate, aggregate, resideu

aggregate aggregate, $\begin{aligned} & \text { aggregate } \\ & \text { residue }\end{aligned}$

Title Abstract Keywords

Article

(Luis de Oliveira Júnior et al., 2019)
Journal

Journal of Building Engineering
The exposure time variable was found to have a greater influence on the carbonation process. Under the conditions analyzed, the granite residue proved to be beneficial, reducing the carbonation depth.

\section{Methodology}

Experimental Research 


\begin{tabular}{|c|c|c|c|c|}
\hline \multicolumn{3}{|c|}{$\begin{array}{l}\text { Palavras aggregate, residue and } \\
\text { concrete }\end{array}$} & \multirow[t]{2}{*}{ objectives } & \multirow[t]{2}{*}{$\begin{array}{l}\text { Main Conclusions or } \\
\text { Proposals }\end{array}$} \\
\hline Title & Abstract & Keywords & & \\
\hline $\begin{array}{l}\text { aggregate, } \\
\text { residue }\end{array}$ & $\begin{array}{l}\text { residue } \\
\text { aggregate, } \\
\text { waste }\end{array}$ & $\begin{array}{l}\text { residue, } \\
\text { waste }\end{array}$ & $\begin{array}{l}\text { To evaluate the effects of } \\
\text { partial replacement of the } \\
\text { natural sand aggregate of } \\
\text { an ecological mortar by } \\
\text { different percentages of } \\
\text { grain residue on the } \\
\text { compressive, flexural and } \\
\text { tensile strength of the } \\
\text { material. }\end{array}$ & $\begin{array}{l}\text { The results indicate a } \\
\text { potential for the use of this } \\
\text { residue as a partial } \\
\text { replacement of fine } \\
\text { aggregates in coating } \\
\text { mortars and suggest that } \\
15 \% \text { can be considered the } \\
\text { ideal replacement ratio. }\end{array}$ \\
\hline
\end{tabular}

Article

(Bacarji et al., 2012)

Palavras aggregate, residue and concrete

Title Abstract Keywords

concrete, concrete, concrete, To study the use of natural waste aggregate, waste

residue,

waste

\section{Journal}

Key Engineering Materials

objectives

sand by two mineral

residues in the production

of concrete.

\section{Methodology}

Experimental Research

Main Conclusions or Proposals
It has been demonstrated that it is possible to obtain self-compacting structural concrete, self-compacting concrete without structural purpose and conventional concrete using mineral residues instead of natural aggregates.

\section{Article}

(Castro Mendes et al., 2020)

Palavras aggregate, residue and concrete

Title

Residue $\begin{aligned} & \text { aggregate, Residue } \\ & \text { residue }\end{aligned}$

\section{Journal}

Journal of Material Cycles and Waste Management

objectives

Check the feasibility of using mining and industrial residues as aggregates of coating mortars in terms of the thermal performance of buildings.

\section{Methodology}

Experimental Research

Main Conclusions or Proposals
Mortars produced with mining and industrial waste can be economical and sustainable solutions to passively improve the thermal performance of buildings, as well as mitigate the impacts of the disposal of this waste.

\section{Article}

(Favaretto et al., 2017)

Palavras aggregate, residue and

\section{Journal}

Applied Sciences-Basel

objectives

Page 8/45

\section{Methodology}

case study

Main Conclusions or 


\section{Title Abstract Keywords}

concrete, concrete, concrete, Evaluate the use of waste aggregate, waste

residue,

waste construction and demolition waste (WCD) from the Passo Fundo region, Rio Grande do Sul (RS), Brazil, in the development of aerated concrete foam.
WCD residues from the study region can be used as aggregates for the development of aerated concrete foam. However, it must be characterized before being used to guarantee the quality of the final product.

\section{Article}

(Zerbino et al., 2011)
Journal

Construction and Building Materials

Objectives

\section{Methodology}

Experimental Research

Main Conclusions or Proposals
Palavras
concrete

Title

concrete

\section{Abstract Keywords}

concrete, concrete, Use rice husk ash without aggregate, waste any grinding (in natura) to residue replace part of the structural concrete aggregates.
The incorporation of natural rice husk ash (without grinding) in the structural concrete represents a good alternative for the disposal of this residue, even without the previous optimization through a grinding process.

\section{Methodology}

Experimental Research

Applied Mechanics and Materials

objectives

Main Conclusions or Proposals concrete

Title Abstract Keywords

concrete, aggregate, residue
Evaluate the incorporation of sludge in the concrete used in the manufacture of concrete blocks.
Blocks were obtained that are classified with structural function, for use in above ground masonry elements, according to the Brazilian standard.

Methodology

Clean Technologies and Environmental Policy

objectives
Experimental Research

Main Conclusions or Proposals concrete

Title

Abstract

Keywords 
concrete, concrete, concrete, To characterize the fine residue aggregate, residue, residue, waste waste fraction of RCA (automotive crushing residue) generated in a plant located in Brazil. It is also proposed to recycle concrete blocks for paving to replace the natural fine aggregate using the Portland cement solidification / stabilization technique.
The concrete paving blocks showed good mechanical and physical performance. Therefore, the produced concrete paving block can be used as a potential solution to mitigate the environmental impact caused by the fine fraction of RCA waste.

\section{Article}

(Pelisser et al., 2011)

Palavras aggregate, residue and concrete

Title Abstract Keywords

$\begin{array}{clll}\text { concrete } & \begin{array}{l}\text { concrete, } \\ \text { aggregate, } \\ \text { residue }\end{array}\end{array} \quad$ Concrete $\quad \begin{aligned} & \text { To Investigate the potential } \\ & \text { for using recycled tire } \\ & \text { rubber in cement matrices. }\end{aligned}$

\section{Methodology}

Journal of Cleaner Production

objectives

Main Conclusions or Proposals
Experimental Research

Rubberized concrete can support the sustainability of construction, minimize the consumption of natural resources with the use of industrial waste and produce a material with special characteristics.

Article
$\begin{aligned} & \text { (Granzotto \& Souza, 2013) } \\
& \text { Palavras aggregate, residue and } \\
& \text { concrete }\end{aligned}$
\begin{tabular}{lll} 
Title & Abstract $\quad$ Keywords \\
$\begin{array}{lll}\text { concrete, } \\
\text { aggregate }\end{array}$ & $\begin{array}{l}\text { concrete, } \\
\text { aggregate, } \\
\text { waste }\end{array}$ & Residue \\
\hline
\end{tabular}

Journal

Acta ScientiarumTechnology

objectives

\section{Methodology}

Experimental Research

Main Conclusions or Proposals
Analyze the behavior of the concrete produced with different proportions of substitution of fine aggregate by rubber waste tires.
Experimental results revealed that additions of rubber of up to $5 \%$ in substitution to sand can produce concretes with medium compressive and tensile strength similar to that obtained for normal strength concrete.
Article

(Fioriti et al., 2010)

Palavras aggregate, residue and concrete
Journal

Acta ScientiarumTechnology

objectives
Methodology

Experimental Research

Main Conclusions or Proposals 


\begin{tabular}{|c|c|c|c|c|}
\hline Title & Abstract & Keywords & & \\
\hline $\begin{array}{l}\text { concrete, } \\
\text { residue }\end{array}$ & $\begin{array}{l}\text { concrete, } \\
\text { aggregate, } \\
\text { residue }\end{array}$ & $\begin{array}{l}\text { concrete, } \\
\text { residue }\end{array}$ & $\begin{array}{l}\text { Investigate the possibility } \\
\text { of using waste tires as part } \\
\text { of the raw material in the } \\
\text { production of interlocking } \\
\text { blocks. }\end{array}$ & $\begin{array}{l}\text { Blocks interlocked with } \\
\text { waste tires can be used in } \\
\text { some environments such as } \\
\text { sidewalks, squares, bike } \\
\text { lanes and residential } \\
\text { condominiums. }\end{array}$ \\
\hline Article & & & Journal & Methodology \\
\hline (Sales et al. & 2010) & & $\begin{array}{l}\text { Construction and Building } \\
\text { Materials }\end{array}$ & Experimental Research \\
\hline $\begin{array}{l}\text { Palavras aq } \\
\text { concrete }\end{array}$ & regate, residu & e and & objectives & $\begin{array}{l}\text { Main Conclusions or } \\
\text { Proposals }\end{array}$ \\
\hline Title & Abstract & Keywords & & \\
\hline concrete & $\begin{array}{l}\text { concrete, } \\
\text { aggregate, } \\
\text { residue }\end{array}$ & Concrete & $\begin{array}{l}\text { Evaluate the potential of } \\
\text { lightweight concrete } \\
\text { produced by replacing part } \\
\text { of the coarse aggregate } \\
\text { with sawdust residue, } \\
\text { together with sludge from } \\
\text { water treatment. }\end{array}$ & $\begin{array}{l}\text { The concrete of this study } \\
\text { presented a set of thermal } \\
\text { properties suitable for the } \\
\text { application of this concrete } \\
\text { in non-structural sealing } \\
\text { elements. }\end{array}$ \\
\hline Article & & & Journal & Methodology \\
\hline (Paz \& Sant & S, 2019) & & $\begin{array}{l}\text { Revista Eletrônica em } \\
\text { Gestão Educação e } \\
\text { Tecnologia Ambiental }\end{array}$ & Experimental Research \\
\hline $\begin{array}{l}\text { Palavras ac } \\
\text { concrete }\end{array}$ & regate, residu & e and & objectives & $\begin{array}{l}\text { Main Conclusions or } \\
\text { Proposals }\end{array}$ \\
\hline Title & Abstract & Keywords & & \\
\hline concrete & $\begin{array}{l}\text { concrete, } \\
\text { aggregate, } \\
\text { residue }\end{array}$ & Concrete & $\begin{array}{l}\text { Analyze the mechanical } \\
\text { performance of concrete } \\
\text { produced with non- } \\
\text { returnable packaging glass } \\
\text { waste. }\end{array}$ & $\begin{array}{l}\text { The concrete with the use of } \\
\text { ground glass obtained an } \\
\text { average resistance of } 32.37 \\
\text { MPa. This result indicates a } \\
\text { technical feasibility of using } \\
\text { the waste. }\end{array}$ \\
\hline Article & & & Journal & Methodology \\
\hline (de Oliveira & indrade et al., & 2018) & $\begin{array}{l}\text { Journal of Cleaner } \\
\text { Production }\end{array}$ & Experimental Research \\
\hline $\begin{array}{l}\text { Palavras ac } \\
\text { concrete }\end{array}$ & regate, residu & e and & objectives & $\begin{array}{l}\text { Main Conclusions or } \\
\text { Proposals }\end{array}$ \\
\hline Title & Abstract & Keywords & & \\
\hline aggregate & $\begin{array}{l}\text { aggregate, } \\
\text { residue, } \\
\text { waste }\end{array}$ & Aggregate & $\begin{array}{l}\text { Investigate the mechanical } \\
\text { properties (bond strength, } \\
\text { compressive strength and } \\
\text { flexural strength), durability }\end{array}$ & $\begin{array}{l}\text { In general, this study } \\
\text { showed that waste, as a } \\
\text { source of fine mortar } \\
\text { aggregates, can be }\end{array}$ \\
\hline
\end{tabular}


(water absorption) and microstructural analysis of coating mortars with different levels of substitution $(2.5 \%$ by weight, $5 \%$ by weight, $7,5 \%$ by weight and $10 \%$ by weight) of natural sand per aggregate of water treatment sludge.

\begin{tabular}{|c|c|c|}
\hline \multicolumn{3}{|l|}{ Article } \\
\hline \multicolumn{3}{|c|}{ (Copetti et al., 2020) } \\
\hline \multicolumn{3}{|c|}{$\begin{array}{l}\text { Palavras aggregate, residue and } \\
\text { concrete }\end{array}$} \\
\hline Title & Abstract & Keywords \\
\hline concrete & $\begin{array}{l}\text { concrete, } \\
\text { residue, } \\
\text { aggregate, } \\
\text { waste }\end{array}$ & Concrete \\
\hline
\end{tabular}

Journal

Journal of Cleaner Production

objectives considered a viable and sustainable alternative for use in the construction sector. The best result was obtained by replacing $5 \%$ of natural sand with sludge.

\section{Methodology}

Experimental Research

Main Conclusions or Proposals
Evaluate the influence of a chemical pretreatment with sodium hydroxide solution $(\mathrm{NaOH})$ on the physical, mechanical and microstructural properties of concrete with two levels of rubber residue $(15 \%$ and $30 \%$ ) as a natural substitute for fine aggregate, and the addition of silica fumes $(7.5 \%$ and $15 \%)$ to replace Portland cement.

\section{Article}

(Molin Filho, Longhi, et al., 2019)

Palavras aggregate, residue and concrete

\section{Title Abstract Keywords}

aggregate, concrete,

residue residue

\section{Journal}

Environment Development and Sustainability

objectives
Although many factors still need to be investigated, it was found that the reuse of rubber residue in concrete without any pre-treatment has no significance in the investigated properties and avoids pre-processing costs and can contribute to an appropriate destination of this material.

\section{Methodology}

Experimental Research

Main Conclusions or Proposals

\begin{tabular}{|llll|}
\hline aggregate, & concrete, & $\begin{array}{l}\text { Develop self-compacting } \\
\text { mortars with partial } \\
\text { replacement of sand by } \\
\text { sugarcane bagasse ash } \\
\text { (SBA). }\end{array}$ & $\begin{array}{l}\text { With the replacement of } \\
40 \% \text { of sand by SBA, it was } \\
\text { possible to reduce by up to } \\
489 \mathrm{~kg} \text { of the sand and } 56\end{array}$ \\
& residue & $\begin{array}{l}\text { kg of cement, to produce } \\
\text { one cubic meter of self- } \\
\text { compacting mortar with } \\
\text { sugarcane bagasse ash. }\end{array}$ \\
\hline Article & Journal & Methodology \\
\hline (Reis \& Jurumenha, 2013) & Materials and Structures & Experimental Research \\
\hline
\end{tabular}




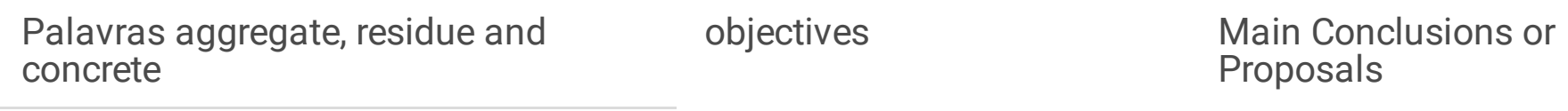

Title Abstract Keywords

$\begin{array}{llll}\text { aggregate } & \text { aggregate, } & \text { Examine the mechanical } & \text { Recycled casting sand can } \\ \text { properties, resistance to } & \text { be used very conveniently to } \\ \text { compression and flexion, of } & \text { produce PM and building } \\ \text { polymeric mortars (PM) } & \text { materials of acceptable } \\ \text { made with used foundry } & \text { quality. } \\ \text { waste, that is, foundry sand } & \text { impregnated with polymer } \\ & & \\ & & \end{array}$

\section{Article}

(Canova et al., 2008)

Palavras aggregate, residue and concrete

\section{Journal}

Acta Scientiarum-

Technology

objectives

Abstract Keywords

Title

concrete, aggregate, Residue aggregate, residue waste

\section{Methodology}

Experimental Research

Main Conclusions or Proposals
To evaluate a coating mortar with tire waste.

\section{Article}

(Almeida et al., 2015)

Palavras aggregate, residue and concrete

Abstract Keywords
aggregate,
residue

Investigate the effect of SBAS (sugarcane bagasse ash) on mortar, specifically its resistance to compression, porosity, depth of carbonation and chloride penetration.

Journal Methodology

Construction and Building Materials

objectives

Main Conclusions or Proposals
The studied product is an alternative that contributes to the reduction of cracks in mortar coatings.

Experimental Research

The substitution of natural sand by SBAS, mainly with a $30 \%$ content, can lead to the maintenance of mechanical properties, clogging of micropores and improvement of the durability of mortars, compared to a reference mixture.

\section{Methodology}

Article Journal Methodology

(Molin Filho, Colpini, et al., 2019)

Clean Technologies and Environmental Policy

Experimental Research

objectives
Main Conclusions or

Proposals

concrete

Title Abstract Keywords 
aggregate, Residue

residue
To characterize bottom, fly and mixed ashes, subjected to low cost processing, in order to better target its applicability in products for civil construction.
The fly ash sample, without late burning and with amorphous structural organization, meets the prerequisites for evaluating pozzolanic applications in partial replacement of cementitious materials.

\section{Article}

(Tonet \& Gorninski, 2013)

Palavras aggregate, residue and concrete

Title Abstract Keywords

concrete, concrete, Concrete waste

$$
\text { aggregate, }
$$

residue

waste
Journal

Construction and building Materials

objectives

To develop innovative polymeric composites produced with residues of industrial alumina, a byproduct of the steel industry.

\section{Methodology}

Experimental Research

Main Conclusions or Proposals
Polymeric concrete made with recycled resin in this study showed compressive strength values between 65.4 and 80.2 MPa. This shows that it is possible to produce PC (Polymer Concrete) composites that meet the current needs of the civil construction sector using environmentally friendly materials, without compromising their properties.

\section{Article}

(Durante Ingunza et al., 2018)

Palavras aggregate, residue and concrete

Title Abstract Keywords

Residue

\section{Journal}

Construction and Building Materials

objectives

\section{Methodology}

Experimental Research

Main Conclusions or Proposals
It studies the performance of mortars with the addition of sludge ash from septic tank.
The results show that the addition of sludge ash from septic tank improves the general condition of mortars, within the limits studied in this work, providing better performance in both the fresh and hardened state.

\section{Article}

(Modolo et al., 2015)

\section{Journal}

Fuel Processing Technology

\section{Methodology}

Experimental Research 

Palavras aggregate, residue and
objectives
Main Conclusions or concrete Proposals

Title Abstract Keywords

$\begin{array}{lll}\text { Aggregate Aggregate } & \begin{array}{l}\text { Investigate the use of ash } \\ \text { residue from forest } \\ \text { biomass as aggregate in } \\ \text { cement-adhesive shroud. }\end{array} \\ \text { residue } & \end{array}$

The use of this type of waste as a raw material in the production of cementitious-adhesive mortar provides environmental benefits with economic advantages for producers of adhesive mortars.

Article
(Rosado et al., 2019)
Palavras aggregate, residue and
concrete

Journal

Keywords

Title

Waste

Abstract

Residue, Waste

waste
Waste Management

objectives

Assess the environmental performance of construction and demolition waste management (C\&DW) in the PCJ Hydrographic Basin area, located in the State of São Paulo, Brazil, through an attributional Life Cycle Assessment.

\section{Methodology}

case study / Life cycle assessment

Main Conclusions or Proposals
In general, the results highlighted the advantages of recovering materials, especially those related to the recycling of steel, glass and plastic. In this sense, municipalities should invest in incentive programs for sorting on construction sites, improving the quality of recovered materials and increasing recycling rates.

\section{Article}

(Hackenhaar et al., 2019)

Palavras aggregate, residue and concrete

$\begin{array}{lll}\text { Title } & \text { Abstract } & \text { Keywords } \\ \text { Waste } & \text { aggregate, } & \begin{array}{l}\text { Explore the basic premises } \\ \text { in proposing a product } \\ \text { system for the recycling } \\ \text { process for RCD } \\ \text { (construction and } \\ \text { demolition waste) in Brazil. }\end{array} \\ \text { waste } & \text { asidue, }\end{array}$

\section{Journal}

Sustainable Built

Environment D-A-Ch

Conference 2019 (SBE19

GRAZ)

objectives

\section{Methodology}

case study / Life cycle assessment

Main Conclusions or Proposals
The identification and availability of information about the representation of $\mathrm{RCD}$ recycling in the Brazilian economic scenario can, together with the inventory of other information, corroborate 
with the elaboration of market data for Brazil.

\begin{tabular}{|c|c|c|c|c|}
\hline \multicolumn{3}{|c|}{ Article } & Journal & Methodology \\
\hline \multicolumn{3}{|c|}{ (Carvalho et al., 2017) } & $\begin{array}{l}\text { Resources, Conservation \& } \\
\text { Recycling }\end{array}$ & Experimental Research \\
\hline \multicolumn{3}{|c|}{$\begin{array}{l}\text { Palavras aggregate, residue and } \\
\text { concrete }\end{array}$} & objectives & $\begin{array}{l}\text { Main Conclusions or } \\
\text { Proposals }\end{array}$ \\
\hline \multirow[t]{2}{*}{ Title } & Abstract & Keywords & & \\
\hline & Waste & Residue & $\begin{array}{l}\text { Evaluates the partial } \\
\text { replacement of blast } \\
\text { furnace slag by slag slag } \\
\text { from the basic oxygen } \\
\text { furnace in the production of } \\
\text { Portland cement. }\end{array}$ & $\begin{array}{l}\text { The cement with the } \\
\text { addition of oxygen oven } \\
\text { slag obtained initial and } \\
\text { final strength gains for all } \\
\text { replacement levels. The use } \\
\text { of oxygen furnace slag as a } \\
\text { partial replacement for blast } \\
\text { furnace slag proves to be a } \\
\text { technical, economical and } \\
\text { environmentally viable } \\
\text { alternative for the cement } \\
\text { industry. }\end{array}$ \\
\hline
\end{tabular}

Article Journal Methodology

(Borges Marinho et al., 2017)

Journal of Materials in Civil Engineering

Palavras aggregate, residue and objectives

Experimental Research

Main Conclusions or

Proposals

$\begin{array}{lll}\text { Title } & \text { Abstract } & \text { Keywords } \\ & \text { Waste } & \text { Waste }\end{array}$

Develop a sustainable binder obtained from LFS (ladle furnace slag), a byproduct of secondary steel refining, replacing hydraulic lime.

Article
(Mizobata et al., 2017)
$\begin{aligned} & \text { Palavras aggregate, residue and } \\ & \text { concrete } \\ & \text { Title Abstract Keywords }\end{aligned}$

Residue Residue

Journal

Ciência Florestal

objectives

Evaluate the growth of Dipteryx alata (baru) and Astronium fraxinifolium (gonçalo-alves) seedlings in degraded soil, compacted or not, supplemented with agroindustrial residue and
The results obtained indicate the technical feasibility of using LFS as a binder for mortar to replace lime.

\section{Methodology}

Experimental Research

Main Conclusions or Proposals
The agro-industrial residue influenced the chemical conditions of the degraded soil, increasing the $\mathrm{pH}$ and the contents of $\mathrm{K}, \mathrm{Ca}$ and $\mathrm{Mg}$, and can be used as a soil conditioner; 
check the possibility of using it as soil conditioner.
Dipteryx alata had the fresh root mass negatively influenced by compaction and was undemanding in relation to the addition of nutrients.

\section{Methodology}

Experimental Research

Revista em Agronegócio e Meio Ambiente, Maringá (PR)

\begin{tabular}{ll}
$\begin{array}{l}\text { Palavras aggregate, residue and } \\
\text { concrete }\end{array}$ & Majectives Conclusions or \\
\hline
\end{tabular}

Title Abstract Keywords

$\begin{array}{cl}\text { concrete } & \begin{array}{l}\text { concrete, } \\ \text { aggregate, }\end{array}\end{array}$

residue
To study the use of sugarcane bagasse ash (SBA) in the replacement of fine aggregate in the manufacture of concrete paving blocks (pavers), subject to light stresses.
SBA proved to be a viable residue for the partial replacement of fine aggregate in the manufacture of pavers as it presents an expressive improvement of the analyzed characteristics (resistance to compression, absorption and abrasion) in relation to pavers manufactured without the partial replacement of sand by SBA.

\begin{tabular}{|c|c|c|c|c|}
\hline \multicolumn{3}{|l|}{ Article } & Journal & Methodology \\
\hline \multicolumn{3}{|c|}{ (Garcia et al., 2018) } & $\begin{array}{l}\text { Sustentabilidade em } \\
\text { Debate }\end{array}$ & Experimental Research \\
\hline \multicolumn{3}{|c|}{$\begin{array}{l}\text { Palavras aggregate, residue and } \\
\text { concrete }\end{array}$} & \multirow[t]{2}{*}{ objectives } & \multirow[t]{2}{*}{$\begin{array}{l}\text { Main Conclusions or } \\
\text { Proposals }\end{array}$} \\
\hline Title & Abstract & Keywords & & \\
\hline $\begin{array}{l}\text { concrete } \\
\text { Aggregate } \\
\text { Residue }\end{array}$ & $\begin{array}{l}\text { concrete, } \\
\text { aggregate, } \\
\text { residue }\end{array}$ & $\begin{array}{l}\text { Residue } \\
\text { Aggregatr }\end{array}$ & $\begin{array}{l}\text { Analyze the use of concrete } \\
\text { block residues to replace } \\
\text { mineral aggregates in } \\
\text { asphalt paving of the hot } \\
\text { machined bituminous } \\
\text { concrete. }\end{array}$ & $\begin{array}{l}\text { The results showed that } \\
\text { composites with } \\
\text { substitutions of mineral } \\
\text { aggregates, up to } 40 \% \text { by } \\
\text { mass, meet the established } \\
\text { requirements and can be } \\
\text { used in asphalt paving. }\end{array}$ \\
\hline
\end{tabular}

Figure 21 shows the occurrence of the words investigated by this work in the title.

Figure 22 shows the occurrence of the words investigated by this work in the abstract.

Figure 23 shows the occurrence of the words investigated by this work in the keywords. 
Figure 24 shows the types of waste, which were studied as substitutes for raw materials in the construction industry, for the articles provided by the base tools.

\section{Discussion}

\subsection{Global considerations}

The results show that 371 articles were found in the Scopus database and 401 in the Web of Sciences database with the characteristics investigated by this present work. The first article with these characteristics identified in the Scopus database was published in 1963. In the Web of Sciences database, it was in 1996. The trend in the annual evolution of publications is similar in both bases (Figs. 1 and 11), showing a trend of increase in the number of publications since 2006. Both bases also have their peak of publications in 2019. It is important to note that the data for 2020 refer to 09/30/2020 for the Scopus database and until 10/07/2020 for the Web of Science database. Thus, it is very likely that the peak of publications will be the year 2020, confirming the trend of increasing publications in both bases.

When analyzing the distribution of articles by country, it appears that in both bases, Brazil is the country that most published articles with the characteristics investigated in this work, both in the Scopus database and in the Web of Sciences database. Here is an observation of what is probably an inconsistency in the Web of Science base, in relation to publications by Brazilian authors. The observation is that on the day of the survey, the database showed that there were 85 articles by authors from Brazil and 5 articles by authors from "Brasil". In other words, there are actually 90 articles with authors from Brazil. It appears that the Web of Science database was unable to identify that "Brasil" is the spelling of Brazil in Portuguese. There is also an observation regarding the Scopus base. The observation is that the database was not able to identify the country of the authors of 41 articles. This number occupies the second position in the ranking of publications by country, that is, it is only behind Brazil, which has the largest number of published articles. This shows that this inconsistency is significant.

Regarding the subject area, Figs. 3 and 12 show that the area that most published articles was Engineering, followed by the Materials Science and Environmental areas. This on both bases. This result was already expected since the study on aggregates for concrete is strictly linked to Civil Engineering and Materials Science. The fact that the environmental area is the third area with the most publications was also expected. Among the reasons for this result, this present work highlights the fact that efficient use of natural resources is the main global political, social and economic agenda (Fargnoli et al., 2014). As a result, consumers are demanding that companies, such as the Civil Construction Company, which is largely responsible for extracting resources from nature (Mefteh et al., 2013), adopt sustainable processes to produce their products (Adeyeye et al., 2017), forcing it to invest in research in this area. 
Another important factor that justifies the positions of the engineering and environmental areas is the increased concern with the destination of waste from the construction industry itself, as this type of waste occupies a lot of space in landfills worldwide (Tam et al., 2018). This factor, together with the fact that the construction industry is a major consumer of natural resources, makes concerns about sustainability occupy more space in this industry (Saieg et al., 2018). The result of these concerns is the production of more research involving the engineering and environmental areas. These researches are mainly focused on replacing natural aggregates with recycled ones, since raw materials, such as aggregates used in concrete, are finite (Onuaguluchi \& Panesar, 2014).

As it is a type of waste that occupies a lot of space in landfills around the world, a large number of studies have been identified suggesting the use of waste from the civil construction industry itself (Tam et al., 2016). An example of this type of study is the one carried out in Turkey, where (Elçi, 2016) investigated the use of tile waste as aggregates in the production of concrete, with the objective of reducing the cost of production and minimizing the environmental impact caused by waste from tiles.

Another type of waste that is being investigated as a substitute for some of the natural aggregates in the production of concrete is agricultural waste. Although research on the use of agricultural waste as a concrete aggregate is relatively new (Shafigh et al., 2014), some studies have been identified in this regard. In their work (Alengaram et al., 2013) they identified 74 studies, only in relation to the use of palm oil as a substitute for part of natural aggregates in the production of concrete. Studies have also been identified that suggest the use of other types of agricultural waste as substitutes for natural aggregates. Residues such as sugar cane ash (Ismail \& Jaeel, 2014) and sugar cane bagasse (Sampaio et al., 2014). Several other studies were also identified indicating the feasibility of using, with acceptable performance, various solid agricultural residues, such as coconut husks, rice husks and tobacco residues as aggregates in the manufacture of concrete (Shafigh et al., 2014).

This work also identified several studies, such as the one carried out which suggest the use of waste tires as part of natural aggregates in the production of concrete.

In addition to the residues, this work identified several other studies suggesting other types of residues as a substitute for natural aggregates in the production of concrete. Among them, the polyethylene terephthalate residue (Frigione, 2010) (Saikia \& De Brito, 2013). Or yet, proposals such as the use of ash from incinerated waste in dumps (Wegen et al., 2013) (Abbà et al., 2014), steel slag (Netinger et al., 2011), iron ore tailings (Shettima et al., 2016) and sewage sludge (Kosior-Kazberuk, 2011).

The analysis of the data referring to articles in the environmental areas are remarkably like the analysis made referring to the data of the total articles in the two databases. The first article, on the Scopus database, was published in 1976 and on the Web of Science database in 1992. The trend, in both bases, is for growth starting in 2006, the same trend seen in both bases when analyzing articles from all areas. The relevant differences in relation to the evolution of the number of publications were found in the Scopus database. The first difference is that the peak in the number of publications was in 2018, as opposed to the peak of publications on articles from all areas, which was in 2019. The second difference 
is that there was a decrease in the number of publications of articles in the environmental area in 2019, while the number of publications for articles in all areas increased. The third difference is that Brazil becomes the second country to publish articles with the characteristics studied in this present work. India is in now first place. The fourth and final difference is the inclusion of the Single Kingdom among the main countries that have published articles.

\subsection{Considerations about articles with Brazilian authors}

Among the main information, in relation to articles with Brazilian authors, the fact that Brazil is in first place in number of publications in both bases stands out. The evolution of the number of articles with published Brazilian authors is similar in both bases. Upward trend with peak in the number of publications in 2019.

Following the global trend, the largest number of Brazilian articles is from the Engineering area, followed by the Materials Science area, in both bases. In third place comes the Construction Building Technology area, on the Web of Science base, and Physics and Astronomy on the Scopus base. The environmental area is in the fourth position, in the Web of Sciences base, and in the fifth position, in the Scopus base. It is worth mentioning that the Engineering, Construction Building Technology and Materials Science areas are related to civil engineering. In this way it is possible to affirm that a large part of the Brazilian articles identified here are from the area of Civil Engineering. The fact that the majority of articles by Brazilian authors are from the engineering area may have as one of the reasons that the construction industry has a great weight in the Brazilian economy (William et al., 2013). In 2014, the construction industry was responsible for $14 \%$ of the Gross Domestic Product (GDP) in Brazil. This industry also has great social importance, since it generates a large part of jobs for the most disadvantaged population (Santana \& Oliveira, 2004).

Despite the articles in the environmental area occupying the fourth (Web of Sciences base) and the fifth (Scopus base) place in the ranking of research areas, when considering only articles with Brazilian authors, these articles occupy a prominent position, globally. In the Web of Science base, it is in first place and in Scopus in second. You also must consider that the keywords investigated here are very much related to engineering. So, it is natural to obtain more articles related to engineering, which was the case.

The fact that the environmental area appears right after the engineering areas is a strong indication that the environmental issue is a truly relevant topic for Brazil. However, considering the relevant environmental issue does not mean having an optimal condition in relation to the environment. Although Brazil publishes a lot about the environmental area, the country has difficulty in dealing with sustainability. Among the main reasons for this difficulty is Brazil's delay in taking concrete actions to achieve sustainability. An example of this delay are actions to tackle the issue of post-consumer waste, which had as a landmark the National Solid Waste Policy (NSWP) (DEMAJOROVIC \& Migliano, 2013). Although the NSWP was regulated on December 23, 2010, it still faces difficulties in its real implementation in relation to the collection, recycling and reverse logistics of various wastes, mainly ewaste (DEMAJOROVIC et al., 2016). The consequence of these delays is the country's difficulty in

Page 20/45 
correctly managing its waste, such as e-waste, which has an estimated collection rate of only $2 \%$ (Azevedo et al., 2017).

\subsection{Considerations on the data in Chart 1}

The first information that this work highlights from Chart 1 is that most studies used the experimental research methodology, with 31 articles, representing more than $88 \%$ of the articles. The rest of the articles used the case study methodology, two of which analyzed the product life cycle.

This present work used the tools of the Scopus and Web of Science databases to identify articles that have the words concrete, aggregate and residue in their title or abstract or Keywords. However, these tools returned articles that did not meet the research parameters, as can be seen in Figs. 21, 22 and 23 . When analyzing the information of the articles, provided by the tools of the databases, in relation to the title of the articles (Fig. 21), it is possible to verify that only two articles met the research parameters. Regarding the information about the abstract (Fig. 22), only 14 articles. And lastly, regarding the Keywords (Fig. 23), no article was identified. It is important to note that in five articles all three words investigated by this work appeared in two items, that is, in the title or in the abstract, in the title or in the Keywords or in the abstract and Keywords. Thus, of the 35 articles provided by the database tools, only 11 fully met the research parameters.

When considering the word "waste", which is a synonym for residue, the number of articles that met the search parameters are 4, 18 and 1 for the titles, abstract and keywords respectively. Subtracting the five articles that contain the words in more than one item, gives a total of 18 articles. Thus, even validating the word "waste", almost $50 \%$ of the articles provided by the databases did not meet the research parameters.

It is worth highlighting the information shown in Fig. 24, where it shows that the waste that is most studied, by the selected articles, is the waste of the civil construction industry itself. This fact shows that Brazilian research follows the global trend, since the waste from the construction industry is the most investigated to be used as a substitute for raw material in this industry. Another important highlight that can be observed in the data in Fig. 24 is in relation to agricultural waste. There are several types of agricultural waste being investigated in these articles. Thus, if agricultural waste is grouped into a single type of waste, it would occupy the first position, with seven articles.

\section{Conclusions}

The words aggregate, residues and concrete are strongly related to the area of Engineering, mainly Civil Engineering. They are also strongly related to environmental areas. This confirms the hypothesis that using these words, in the search for articles on substitution of natural aggregates for recycled ones, is an efficient way to start a research on the subject. This search will return many articles dealing with engineering and environmental issues. 
The result of the search in the articles, from the Environmental area of Brazilian authors, showed that the word "waste" had a higher frequency than the word "residue". Thus, this work evaluates that it is important to include the word "waste" as a parameter in research when the objective is to investigate the replacement of natural aggregate by waste in the production of material for the civil engineering industry.

The positive evolution of the number of publications with the words aggregates, residues and concrete in the title, or in the summary or in the key words, shows the commitment of organizations to sustainability. This evolution occurs both in articles in the engineering and environmental areas, as well as in the sum of articles in all areas.

Brazil is the country with the largest number of articles published in the Scopus and Web of Sciences databases when considering all areas. It is also the first in the environmental field at the Web of Sciences database. At the Scopus base, it is in second place. These positions in Brazil show the country's commitment to sustainability. However, Brazil still faces great challenges to achieve it, mainly in relation to waste management.

This work suggests that the Web of Science and Scopus databases analyze the possibility of reviewing the data available in their article databases. It also suggests a review of the grassroots research tools. The reasons for these suggestions are that an inconsistency in the number of articles with Brazilian authors was identified in the Web of Science database and a large number of articles without identifying the nationality of the authors in the Scopus database. In addition to these inconsistencies in the databases, it was identified that the search engines returned articles that did not fully meet the research requirements.

The research result, showing that the word "waste" occurred more than the word "residue", suggests that it is important to include the word "waste" as a search parameter. What will be done in a future work to compare with this one.

\section{Declarations}

\section{Acknowledgment}

- Federal Institute of Education, Science and Technology of South of Minas Gerais - IFSULDEMINAS

- Federal University of Itajubá - UNIFEI

\section{Ethics approval and consent to participate}

Not applicable.

\section{Consent for publication}

Not applicable. 
Availability of data and materials

All data generated or analysed during this study are included in this published article.

\section{Competing interests}

The authors declare that they have no competing interests.

\section{Funding}

Not applicable.

\section{Authors' contributions}

JHFG, VCS and CHPM defined the theme, suggested the research bases and guided the review process. CAA performed the searches in the databases, produced the graphics with the data obtained in the articles, performed the analysis on the data and issued the conclusions.

\section{References}

Abbà, A., Collivignarelli, M. C., Sorlini, S., \& Bruggi, M. (2014). On the reliability of reusing bottom ash from municipal solid waste incineration as aggregate in concrete. Composites Part B: Engineering, 58, 502509. https://doi.org/10.1016/j.compositesb.2013.11.008

Adeyeye, K., She, K., \& Baïri, A. (2017). Design factors and functionality matching in sustainability products: A study of eco-showerheads. Journal of Cleaner Production, 142, 4214-4229.

https://doi.org/10.1016/j.jclepro.2016.11.143

Afonso, M., Ferreira, R., Ribeiro, L. C. L. J., Lintz, R. C. C., Gachet-Barbosa, L. A., \& Pires, M. S. G. (2013). Building Blocks Production with Sludge. Applied Mechanics and Materials, 368-370(1), 860-863. https://doi.org/10.4028/www.scientific.net/AMM.368-370.860

Alengaram, U. J., Muhit, B. A. Al, \& Jumaat, M. Z. Bin. (2013). Utilization of oil palm kernel shell as lightweight aggregate in concrete - A review. In Construction and Building Materials (Vol. 38, pp. 161172). https://doi.org/10.1016/j.conbuildmat.2012.08.026

Almeida, F. C. R., Sales, A., Moretti, J. P., \& Mendes, P. C. D. (2015). Sugarcane bagasse ash sand (SBAS): Brazilian agroindustrial by-product for use in mortar. Construction and Building Materials, 82, 31-38. https://doi.org/10.1016/j.conbuildmat.2015.02.039

Amorim Júnior, N. S., Silva, G. A. O., \& Ribeiro, D. V. (2018). Effects of the incorporation of recycled aggregate in the durability of the concrete submitted to freeze-thaw cycles. Construction and Building Materials, 161, 723-730. https://doi.org/10.1016/j.conbuildmat.2017.12.076 
Askham, C., Gade, A. L., \& Hanssen, O. J. (2012). Combining REACH, environmental and economic performance indicators for strategic sustainable product development. Journal of Cleaner Production, 35, 71-78. https://doi.org/10.1016/j.jclepro.2012.05.015

Azevedo, L. P., da Silva Araújo, F. G., Lagarinhos, C. A. F., Tenório, J. A. S., \& Espinosa, D. C. R. (2017). Ewaste management and sustainability: a case study in Brazil. Environmental Science and Pollution Research, 24(32), 25221-25232. https://doi.org/10.1007/s11356-017-0099-7

Bacarji, E., Marques, V. C., \& Toledo Filho, R. D. (2012). Self-Compacting and Conventional Concrete with Mineral Waste: Fresh and Hardened State Properties. Key Engineering Materials, 517, 547-555. https://doi.org/10.4028/www.scientific.net/KEM.517.547

Borges Marinho, A. L., Mol Santos, C. M., Carvalho, J. M. F. de, Mendes, J. C., Brigolini, G. J., \& André Fiorotti Peixoto, R. (2017). Ladle Furnace Slag as Binder for Cement-Based Composites. Journal of Materials in Civil Engineering, 29(11), 04017207. https://doi.org/10.1061/(ASCE)MT.1943-5533.0002061

Caetano, J. A., Schalch, V., \& Pablos, J. M. (2020). Characterization and recycling of the fine fraction of automotive shredder residue (ASR) for concrete paving blocks production. Clean Technologies and Environmental Policy, 22(4), 835-847. https://doi.org/10.1007/s10098-020-01825-y

Canova, J. A., Bergamasco, R., \& Angelis Neto, G. De. (2008). A utilização de resíduos de pneus inservíveis em argamassa de revestimento. Acta Scientiarum. Technology, 29(2), 141-149.

https://doi.org/10.4025/actascitechnol.v29i2.583

Carvalho, S. Z., Vernilli, F., Almeida, B., Demarco, M., \& Silva, S. N. (2017). The recycling effect of BOF slag in the portland cement properties. Resources, Conservation and Recycling, 127(August), 216-220. https://doi.org/10.1016/j.resconrec.2017.08.021

Castro Mendes, J., Barreto, R. R., de Freitas Vilaça, V., Lopes, A. V., de Souza, H. A., \& Peixoto, R. A. F. (2020). Coating mortars based on mining and industrial residues. Journal of Material Cycles and Waste Management, 22(5), 1569-1586. https://doi.org/10.1007/s10163-020-01051-0

Copetti, C. M., Borges, P. M., Squiavon, J. Z., da Silva, S. R., \& de Oliveira Andrade, J. J. (2020). Evaluation of tire rubber surface pre-treatment and silica fume on physical-mechanical behavior and microstructural properties of concrete. Journal of Cleaner Production, 256, 120670.

https://doi.org/10.1016/j.jclepro.2020.120670

Coppio, G. J. L., de Lima, M. G., Lencioni, J. W., Cividanes, L. S., Dyer, P. P. O. L., \& Silva, S. A. (2019). Surface electrical resistivity and compressive strength of concrete with the use of waste foundry sand as aggregate. Construction and Building Materials, 212, 514-521.

https://doi.org/10.1016/j.conbuildmat.2019.03.297 
da Silva, J. L., Campos, D. B. da C., Lordsleem, A. C., \& Povoas, Y. V. (2020). Influence of the partial substitution of fine aggregate by granite powder in mortar on the process of natural carbonation. Waste Management \& Research, 38(3), 254-262. https://doi.org/10.1177/0734242X19870599

de Oliveira Andrade, J. J., Wenzel, M. C., da Rocha, G. H., \& da Silva, S. R. (2018). Performance of rendering mortars containing sludge from water treatment plants as fine recycled aggregate. Journal of Cleaner Production, 192, 159-168. https://doi.org/10.1016/j.jclepro.2018.04.246

DEMAJOROVIC, J., AUGUSTO, E. E. F., \& SOUZA, M. T. S. DE. (2016). REVERSE LOGISTICS OF E-WASTE IN DEVELOPING COUNTRIES: CHALLENGES AND PROSPECTS FOR THE BRAZILIAN MODEL. Ambiente \& Sociedade, 19(2), 117-136. https://doi.org/10.1590/1809-4422ASOC141545V1922016

DEMAJOROVIC, J., \& Migliano, J. E. B. (2013). POLÍTICA NACIONAL DE RESÍDUOS SÓLIDOS E SUAS IMPLICAÇÕES NA CADEIA DA LOGÍSTICA REVERSA DE MICROCOMPUTADORES NO BRASIL. Gestão $e$ Regionalidade, 29(87), 64-80. https://doi.org/10.13037/gr.vol29n87.2155

dos Anjos, M. A. G., Sales, A. T. C., \& Andrade, N. (2017). Blasted copper slag as fine aggregate in Portland cement concrete. Journal of Environmental Management, 196, 607-613.

https://doi.org/10.1016/j.jenvman.2017.03.032

Durante Ingunza, M. del P., Camarini, G., \& Murilo Silva da Costa, F. (2018). Performance of mortars with the addition of septic tank sludge ash. Construction and Building Materials, 160, 308-315. https://doi.org/10.1016/j.conbuildmat.2017.11.053

Elçi, H. (2016). Utilisation of crushed floor and wall tile wastes as aggregate in concrete production. Journal of Cleaner Production, 112, 742-752. https://doi.org/10.1016/j.jclepro.2015.07.003

Fargnoli, M., De Minicis, M., \& Tronci, M. (2014). Design Management for Sustainability: An integrated approach for the development of sustainable products. Journal of Engineering and Technology Management - JET-M, 34, 29-45. https://doi.org/10.1016/j.jengtecman.2013.09.005

Favaretto, P., Hidalgo, G., Sampaio, C., Silva, R., \& Lermen, R. (2017). Characterization and Use of Construction and Demolition Waste from South of Brazil in the Production of Foamed Concrete Blocks. Applied Sciences, 7(10), 1090. https://doi.org/10.3390/app7101090

Fioriti, C. F., Ino, A., \& Akasaki, J. L. (2010). Análise experimental de blocos intertravados de concreto com adição de resíduos do processo de recauchutagem de pneus. Acta Scientiarum. Technology, 32(3), 237244. https://doi.org/10.4025/actascitechnol.v32i3.6013

Frigione, M. (2010). Recycling of PET bottles as fine aggregate in concrete. Waste Management, 30(6), 1101-1106. https://doi.org/10.1016/j.wasman.2010.01.030

Garcia, G. D. M., Barreto, M. R., \& Crispim, F. A. (2018). Substituição de agregados minerais por resíduos de concreto na fabricação de pavimento asfáltico. Sustentabilidade Em Debate, 9(3), 185-197. 
Gómez-Baggethun, E., \& Naredo, J. M. (2015). In search of lost time: the rise and fall of limits to growth in international sustainability policy. Sustainability Science, 10(3), 385-395.

https://doi.org/10.1007/s11625-015-0308-6

Granzotto, L., \& Souza, R. A. de. (2013). Mechanical properties of structural concrete with partial replacement of fine aggregate by tire rubber. Acta Scientiarum. Technology, 35(1), 39-44. https://doi.org/10.4025/actascitechnol.v35i1.11283

Hackenhaar, I. C., Waskow, R. P., Tubino, R., \& Passuello, A. (2019). Life Cycle Assessment applied to construction and demolition waste treatment: proposal of a Brazilian scenario. IOP Conference Series: Earth and Environmental Science, 323(1), 012054. https://doi.org/10.1088/1755-1315/323/1/012054

Ismail, Z. Z., \& Jaeel, A. J. (2014). A novel use of undesirable wild giant reed biomass to replace aggregate in concrete. Construction and Building Materials, 67, 68-73.

https://doi.org/10.1016/j.conbuildmat.2013.11.064

Khalili, N. R., Duecker, S., Ashton, W., \& Chavez, F. (2015). From cleaner production to sustainable development: The role of academia. Journal of Cleaner Production, 96, 30-43. https://doi.org/10.1016/j.jclepro.2014.01.099

Khankhaje, E., Rafieizonooz, M., Salim, M. R., Mirza, J., Salmiati, \& Hussin, M. W. (2017). Comparing the effects of oil palm kernel shell and cockle shell on properties of pervious concrete pavement. International Journal of Pavement Research and Technology, 10(5), 383-392. https://doi.org/10.1016/j.ijprt.2017.05.003

Khankhaje, E., Salim, M. R., Mirza, J., Hussin, M. W., \& Rafieizonooz, M. (2016). Properties of sustainable lightweight pervious concrete containing oil palm kernel shell as coarse aggregate. Construction and Building Materials, 126, 1054-1065. https://doi.org/10.1016/j.conbuildmat.2016.09.010

Kosior-Kazberuk, M. (2011). Application of SSA as partial replacement of aggregate in concrete. Polish Journal of Environmental Studies, 20(2), 365-370.

Lima, A. J. M. de, \& Iwakiri, S. (2014). Utilização de resíduos da madeira de Pinus spp. como substituição ao agregado miúdo na produção de blocos de concreto para alvenaria estrutural. Ciência Florestal, 24(1), 223-235. https://doi.org/10.5902/1980509813339

Luis de Oliveira Júnior, A., Pedroti, L. G., de Assis Oliveira, J., Hilarino Fernandes, W. E., Fineza, A. G., Monteiro, S. N., \& Nalon, G. H. (2019). The influence of partial replacement of natural sand aggregates by grits residues on the mechanical properties of an ecological mortar. Journal of Building Engineering, 26(August), 100912. https://doi.org/10.1016/j.jobe.2019.100912 
Martins, C. H., \& Altoé, S. P. S. (2015). Assessment of ashes from sugar cane bagasse in the manufacture of concrete pavers | Avaliação da utilização da cinza de bagaço de canade-açúcar na confecção de blocos de concreto para pavimentação. Revista Em Agronegocio e Meio Ambiente, 8, 39-54. https://doi.org/10.17765/2176-9168.2015v8Ed.esp.p39-54

Mefteh, H., Kebaïli, O., Oucief, H., Berredjem, L., \& Arabi, N. (2013). Influence of moisture conditioning of recycled aggregates on the properties of fresh and hardened concrete. Journal of Cleaner Production, 54, 282-288. https://doi.org/10.1016/j.jclepro.2013.05.009

Mizobata, K. K. G. da S., Cassiolato, A. M. R., \& Maltoni, K. L. (2017). CRESCIMENTO DE MUDAS DE BARU E GONÇALO-ALVES EM SOLO DEGRADADO, SUPLEMENTADO COM RESÍDUO, EM ILHA SOLTEIRA - SP. Ciência Florestal, 27(2), 429. https://doi.org/10.5902/1980509827726

Modolo, R. C. E., Silva, T., Senff, L., Tarelho, L. A. C., Labrincha, J. A., Ferreira, V. M., \& Silva, L. (2015). Bottom ash from biomass combustion in BFB and its use in adhesive-mortars. Fuel Processing Technology, 129, 192-202. https://doi.org/10.1016/j.fuproc.2014.09.015

Molin Filho, R. G. D., Colpini, L. M. S., Ferrer, M. M., Nagano, M. F., Rosso, J. M., Volnistem, E. A., Paraíso, P. R., \& de Matos Jorge, L. M. (2019). Characterization of different sugarcane bagasse ashes generated for preparation and application as green products in civil construction. Clean Technologies and Environmental Policy, 21(8), 1687-1698. https://doi.org/10.1007/s10098-019-01740-x

Molin Filho, R. G. D., Longhi, D. A., de Souza, R. C. T., Ferrer, M. M., Vanderlei, R. D., Paraíso, P. R., \& Jorge, L. M. de M. (2019). Self-compacting mortar with sugarcane bagasse ash: development of a sustainable alternative for Brazilian civil construction. Environment, Development and Sustainability, 21(5), 21252143. https://doi.org/10.1007/s10668-018-0127-x

Netinger, I., Bjegović, D., \& Vrhovac, G. (2011). Utilisation of steel slag as an aggregate in concrete. Materials and Structures, 44(9), 1565-1575. https://doi.org/10.1617/s11527-011-9719-8

Onuaguluchi, O., \& Panesar, D. K. (2014). Hardened properties of concrete mixtures containing pre-coated crumb rubber and silica fume. Journal of Cleaner Production, 82, 125-131.

https://doi.org/10.1016/j.jclepro.2014.06.068

Paz, L. A. F. da, \& Santos, V. D. dos. (2019). Reuse of glass in concrete: a study of the production and mechanical performance of resistance. Revista Eletrônica Em Gestão, Educação e Tecnologia Ambiental, 23, 23. https://doi.org/10.5902/2236117036187

Pelisser, F., Zavarise, N., Longo, T. A., \& Bernardin, A. M. (2011). Concrete made with recycled tire rubber: Effect of alkaline activation and silica fume addition. Journal of Cleaner Production, 19(6-7), 757-763. https://doi.org/10.1016/j.jclepro.2010.11.014 
Rangel, C. S., Toledo Filho, R. D., Amario, M., Pepe, M., de Castro Polisseni, G., \& Puente de Andrade, G. (2019). Generalized quality control parameter for heterogenous recycled concrete aggregates: A pilot scale case study. Journal of Cleaner Production, 208, 589-601.

https://doi.org/10.1016/j.jclepro.2018.10.110

Reis, J. M. L., \& Jurumenha, M. A. G. (2013). Investigation on the effects of polymer impregnated aggregate on polymer mortars properties. Materials and Structures, 46(8), 1383-1388.

https://doi.org/10.1617/s11527-012-9980-5

Rosado, L. P., Vitale, P., Penteado, C. S. G., \& Arena, U. (2019). Life cycle assessment of construction and demolition waste management in a large area of São Paulo State, Brazil. Waste Management, 85, 477489. https://doi.org/10.1016/j.wasman.2019.01.011

Saieg, P., Sotelino, E. D., Nascimento, D., \& Caiado, R. G. G. (2018). Interactions of Building Information Modeling, Lean and Sustainability on the Architectural, Engineering and Construction industry: A systematic review. Journal of Cleaner Production, 174, 788-806.

https://doi.org/10.1016/j.jclepro.2017.11.030

Saikia, N., \& De Brito, J. (2013). Waste polyethylene terephthalate as an aggregate in concrete. Materials Research, 16(2), 341-350. https://doi.org/10.1590/S1516-14392013005000017

Sales, A., de Souza, F. R., dos Santos, W. N., Zimer, A. M., \& do Couto Rosa Almeida, F. (2010). Lightweight composite concrete produced with water treatment sludge and sawdust: Thermal properties and potential application. Construction and Building Materials, 24(12), 2446-2453.

https://doi.org/10.1016/j.conbuildmat.2010.06.012

Sampaio, Z. L. M., Souza, P. A. B. F., \& Gouveia, B. G. (2014). Analysis of the influence of the sugar cane bagasse ashes on mechanical behavior of concrete Análise da influência das cinzas do bagaço de canade-açúcar no comportamento mecânico de concretos. 7(4), 626-636.

Santana, V. S., \& Oliveira, R. P. (2004). [Health and work in the construction industry in an urban area of Brazil]. Cadernos de Saude Publica, 20(3), 797-811. https://doi.org//S0102-311X2004000300017

Shafigh, P., Mahmud, H. Bin, Jumaat, M. Z., \& Zargar, M. (2014). Agricultural wastes as aggregate in concrete mixtures - A review. Construction and Building Materials, 53, 110-117.

https://doi.org/10.1016/j.conbuildmat.2013.11.074

Shettima, A. U., Hussin, M. W., Ahmad, Y., \& Mirza, J. (2016). Evaluation of iron ore tailings as replacement for fine aggregate in concrete. Construction and Building Materials, 120, 72-79.

https://doi.org/10.1016/j.conbuildmat.2016.05.095

Tam, V. W. Y., Butera, A., \& Le, K. N. (2016). Carbon-conditioned recycled aggregate in concrete production. Journal of Cleaner Production, 133, 672-680. https://doi.org/10.1016/j.jclepro.2016.06.007 
Tam, V. W. Y., Soomro, M., \& Evangelista, A. C. J. (2018). A review of recycled aggregate in concrete applications (2000-2017). Construction and Building Materials, 172, 272-292.

https://doi.org/10.1016/j.conbuildmat.2018.03.240

Tonet, K. G., \& Gorninski, J. P. (2013). Polymer concrete with recycled PET: The influence of the addition of industrial waste on flammability. Construction and Building Materials, 40, 378-389.

https://doi.org/10.1016/j.conbuildmat.2012.09.049

Wegen, G. van der, Hofstra, U., \& Speerstra, J. (2013). Upgraded MSWI bottom ash as aggregate in concrete. Waste and Biomass Valorization, 4(4), 737-743. https://doi.org/10.1007/s12649-013-9255-6

William, M., Machado, K., Paulo, P., \& Junior, A. (2013). Evaluation of Production in Seasonality Periods: Analysis of the Construction. June, 278-300. https://doi.org/10.14807/ijmp.v4i1.57

Zerbino, R., Giaccio, G., \& Isaia, G. C. (2011). Concrete incorporating rice-husk ash without processing. Construction and Building Materials, 25(1), 371-378. https://doi.org/10.1016/j.conbuildmat.2010.06.016

\section{Figures}

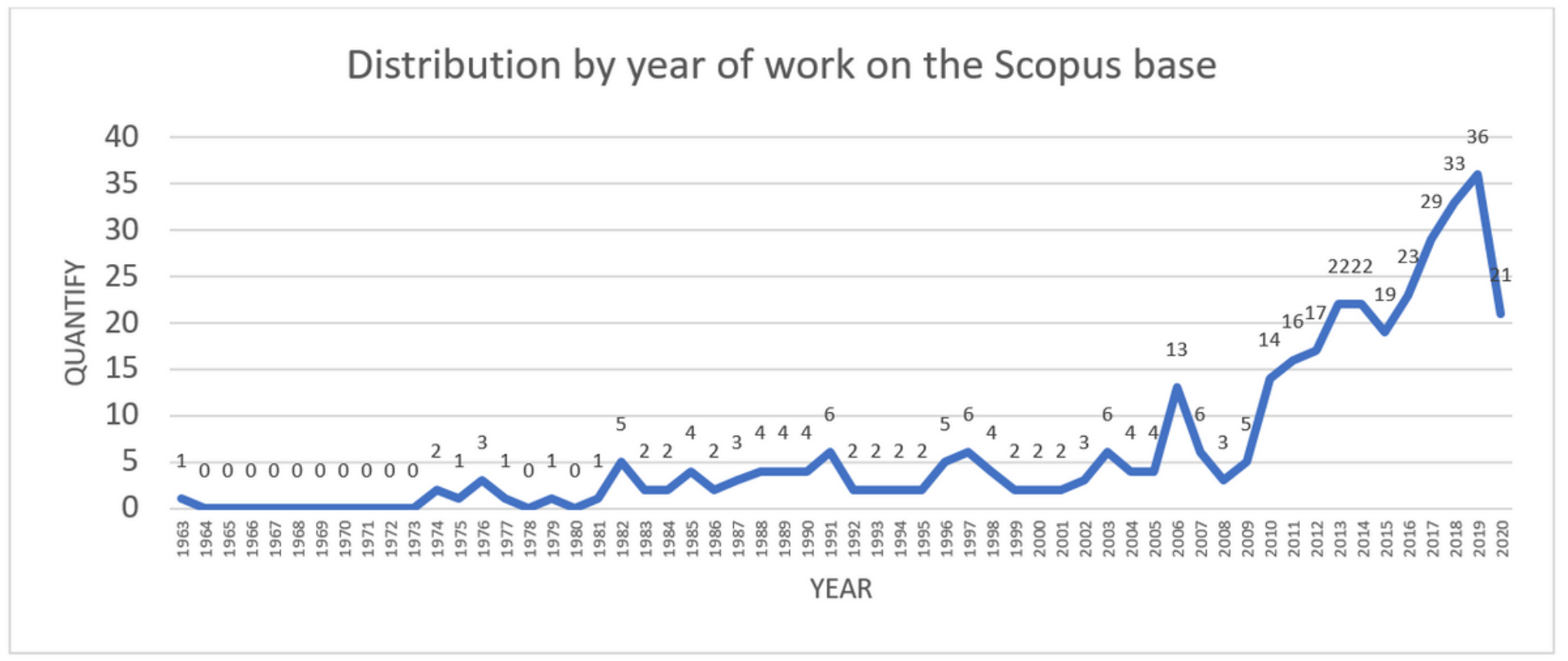

\section{Figure 1}

Distribution, by year of publication, of the articles researched in the Scopus database. 


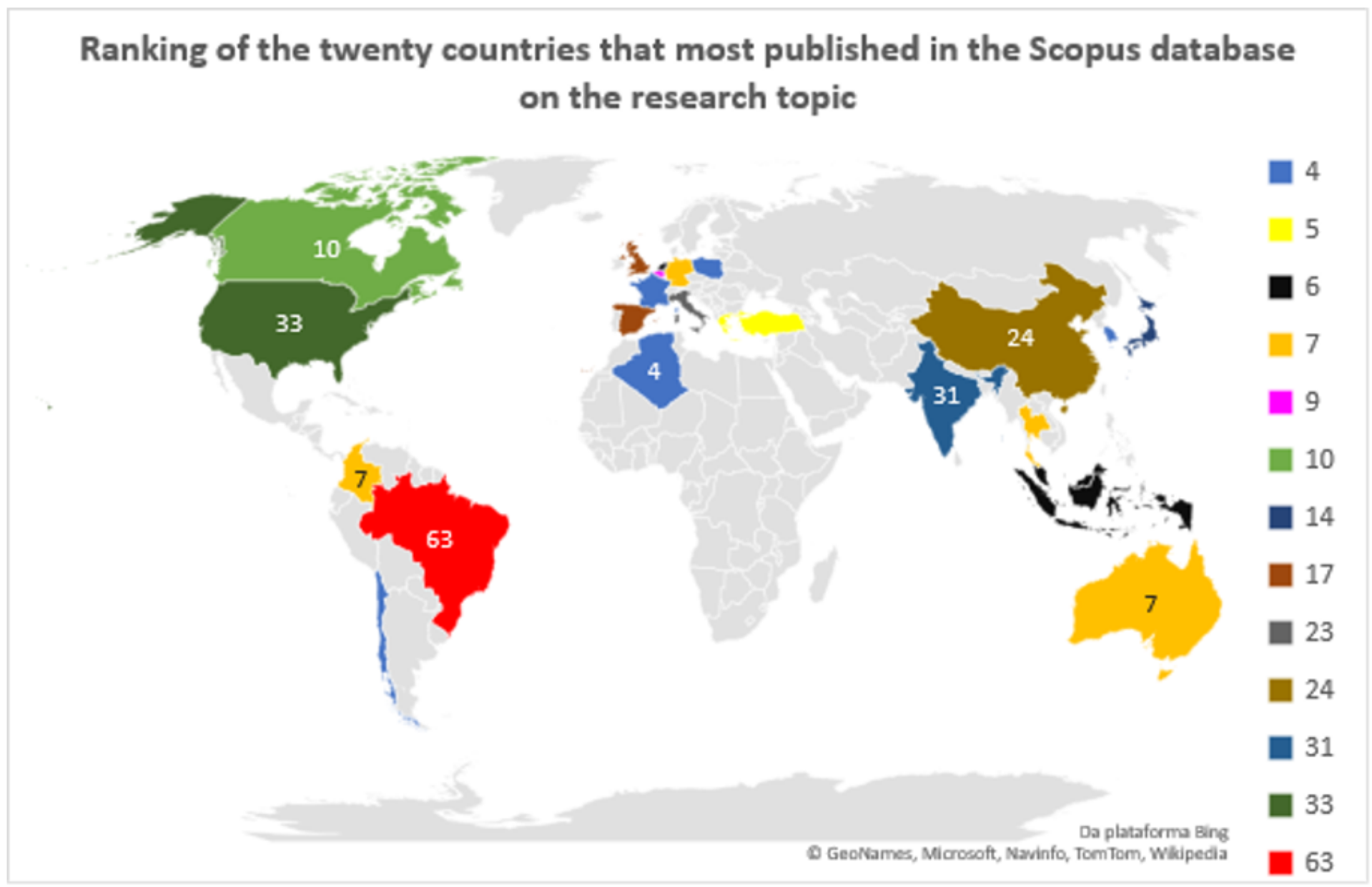

Figure 2

The 20 countries that most published articles with the words aggregates, residues, concrete in the title or keywords or in the abstract. Note: The designations employed and the presentation of the material on this map do not imply the expression of any opinion whatsoever on the part of Research Square concerning the legal status of any country, territory, city or area or of its authorities, or concerning the delimitation of its frontiers or boundaries. This map has been provided by the authors. 


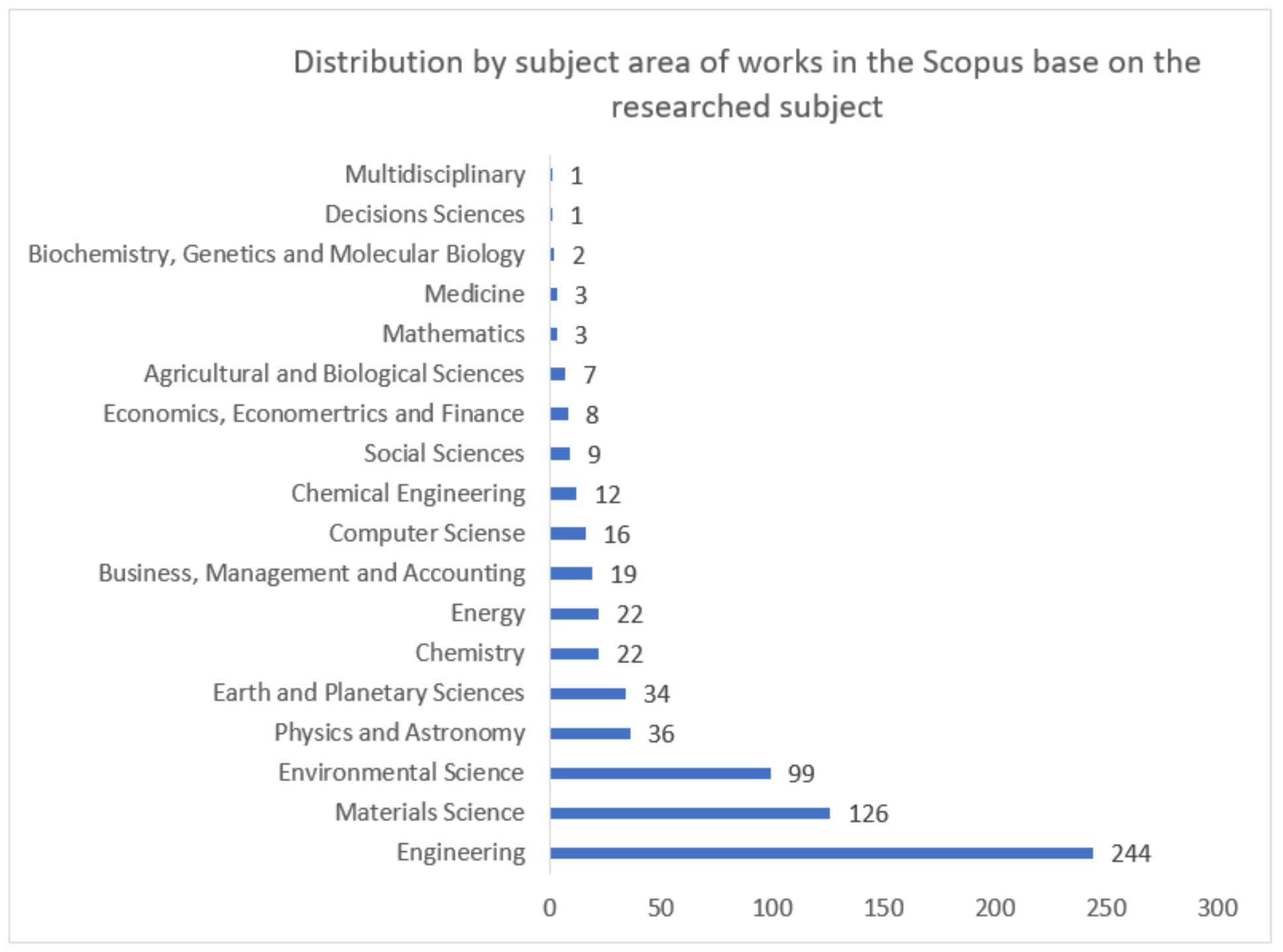

\section{Figure 3}

Articles found in the Scopus database by subject area 


\section{Articles by country of authors Scopus Base}

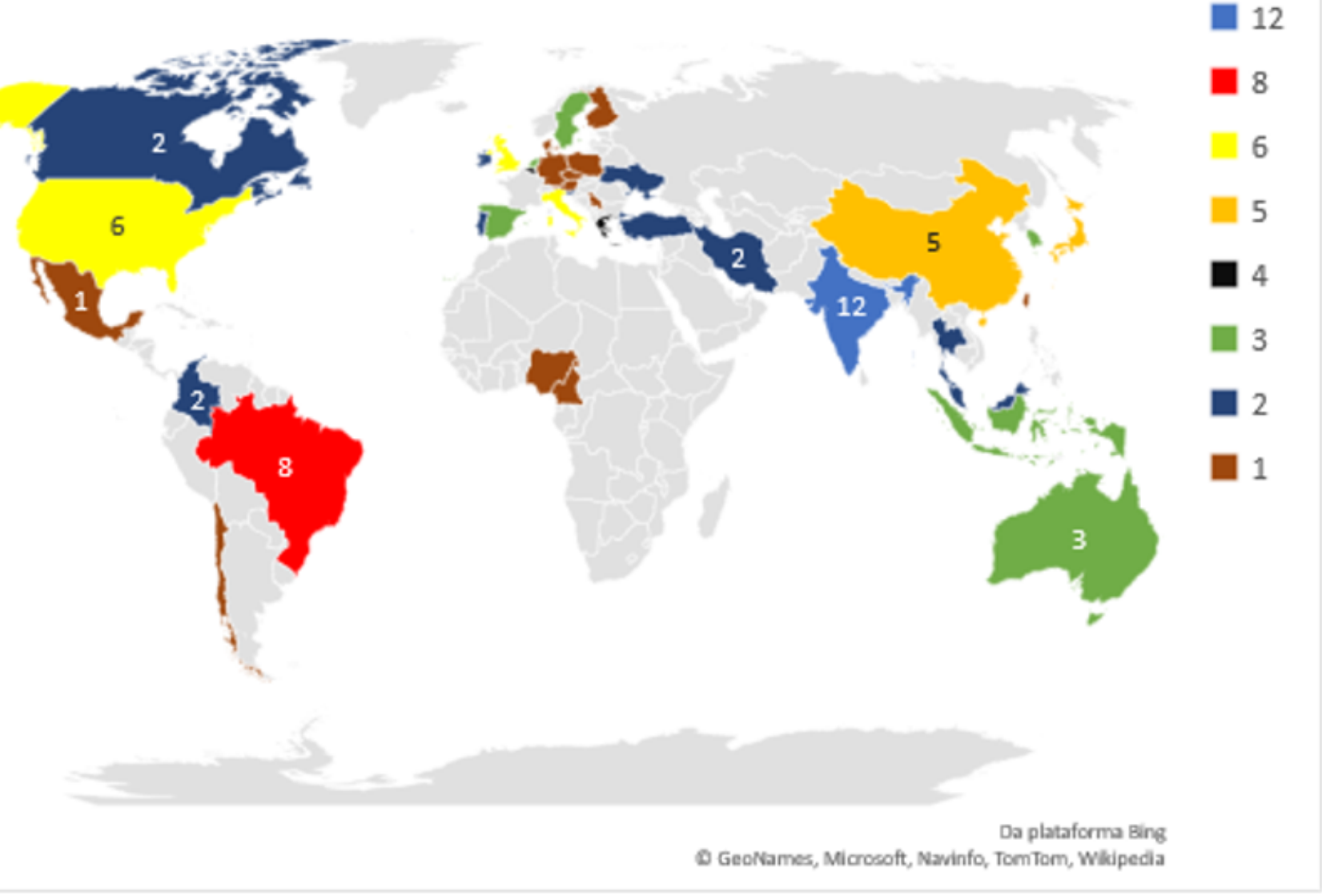

\section{Figure 4}

Distribution, by country, of the 99 articles in the Environmental Science subject area, containing the words aggregates, residues and concrete in the title or in the keywords or in the abstract. Note: The designations employed and the presentation of the material on this map do not imply the expression of any opinion whatsoever on the part of Research Square concerning the legal status of any country, territory, city or area or of its authorities, or concerning the delimitation of its frontiers or boundaries. This map has been provided by the authors. 


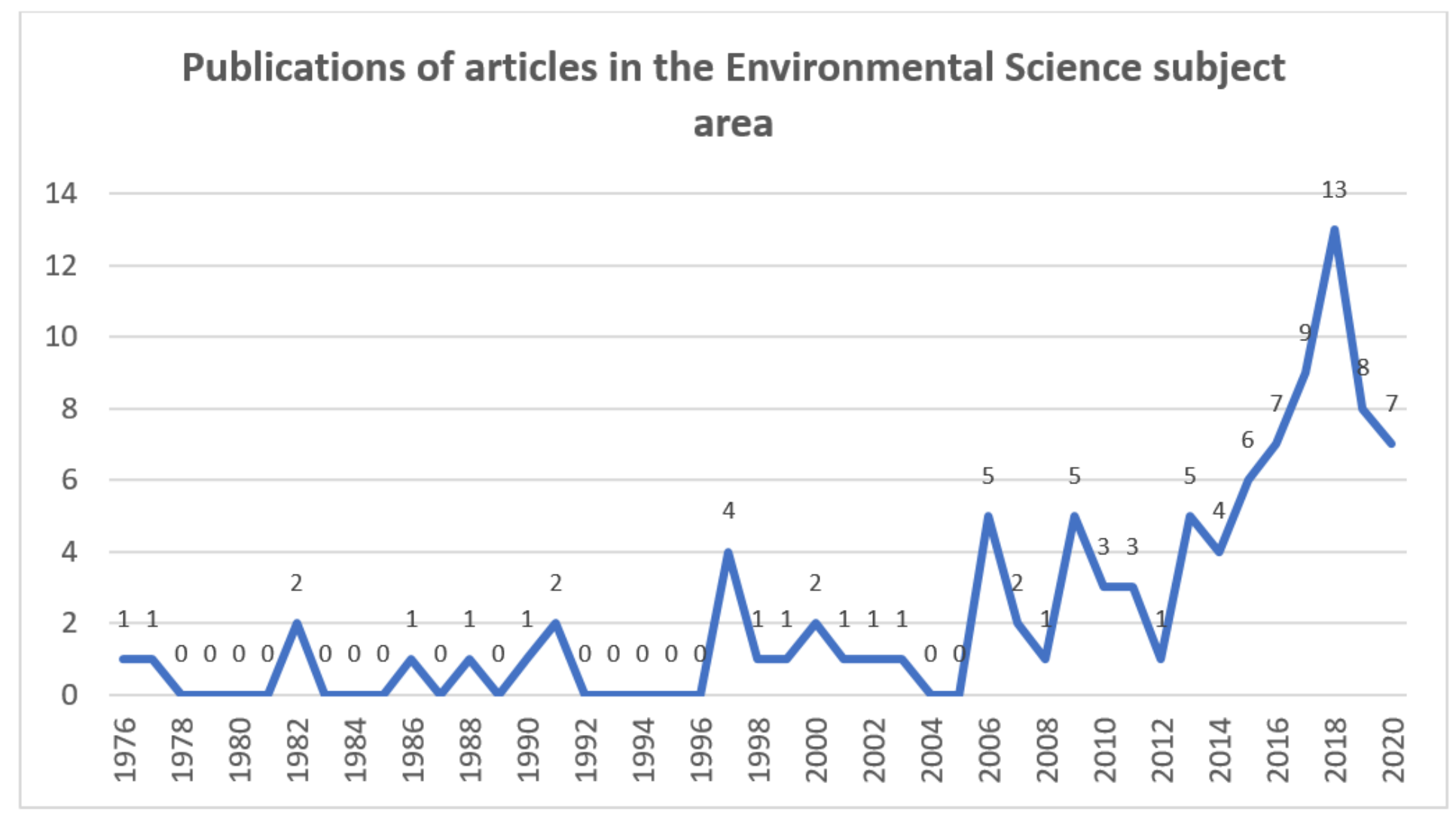

\section{Figure 5}

Evolution of the number of publications of articles in the Environmental Science subject area in the base Scopus 


\section{Main information in the Scopus database}

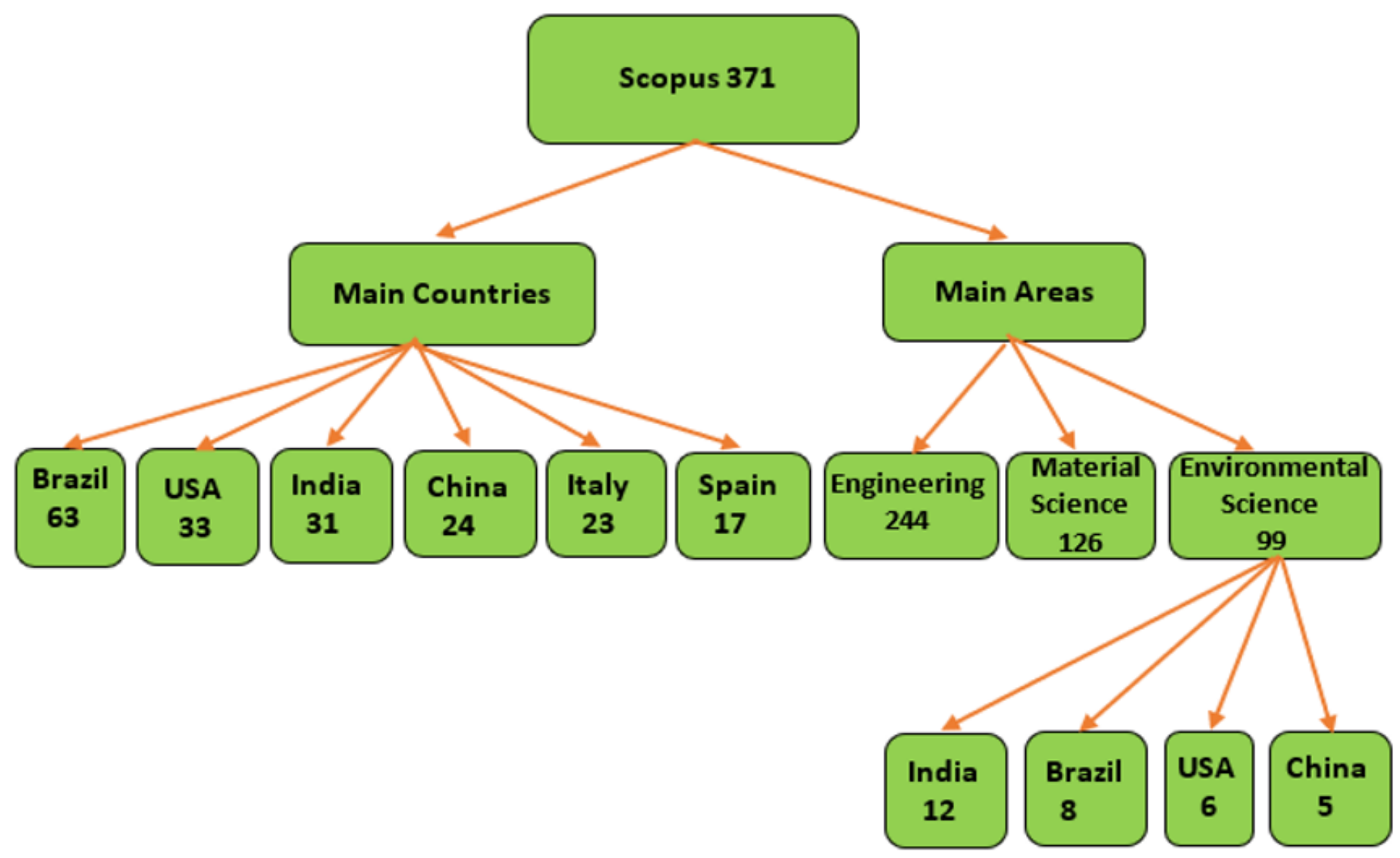

Figure 6

Summary of the main information obtained in the Scopus base of articles with the words aggregates, residues and concrete in the title, abstract or keywords

\section{Brazilian publications by year}

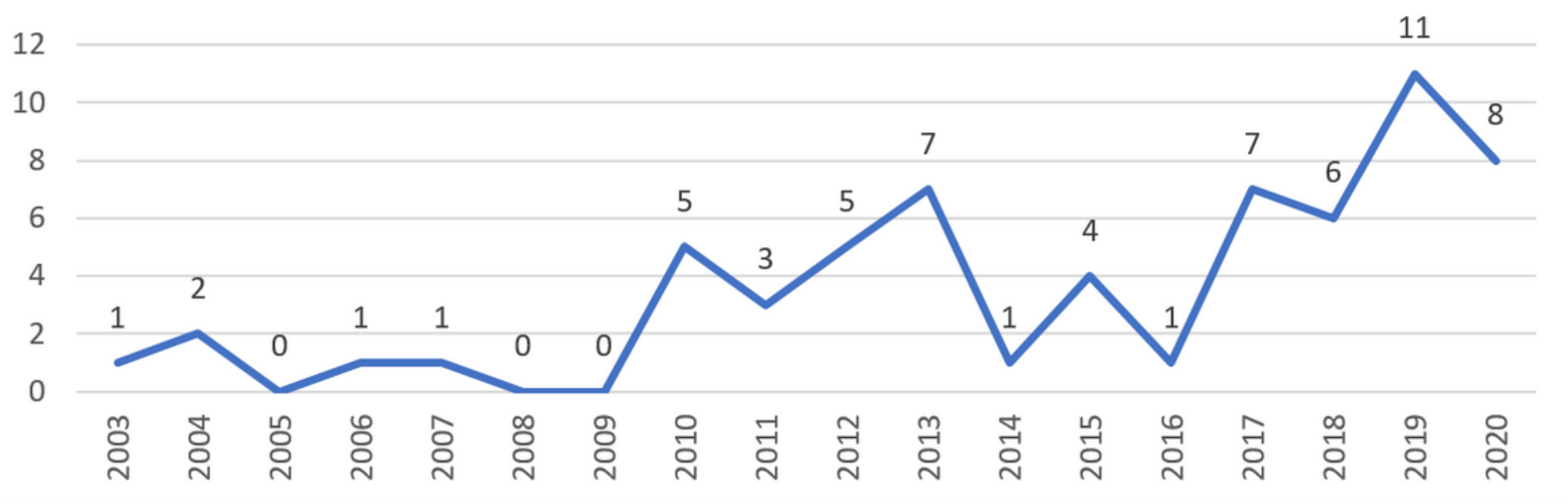

Figure 7 
Evolution of the number of Brazilian publications of articles with the words aggregates, residues and concrete in the title or in the keywords or in the abstract

\section{Brazilian articles by subject area}

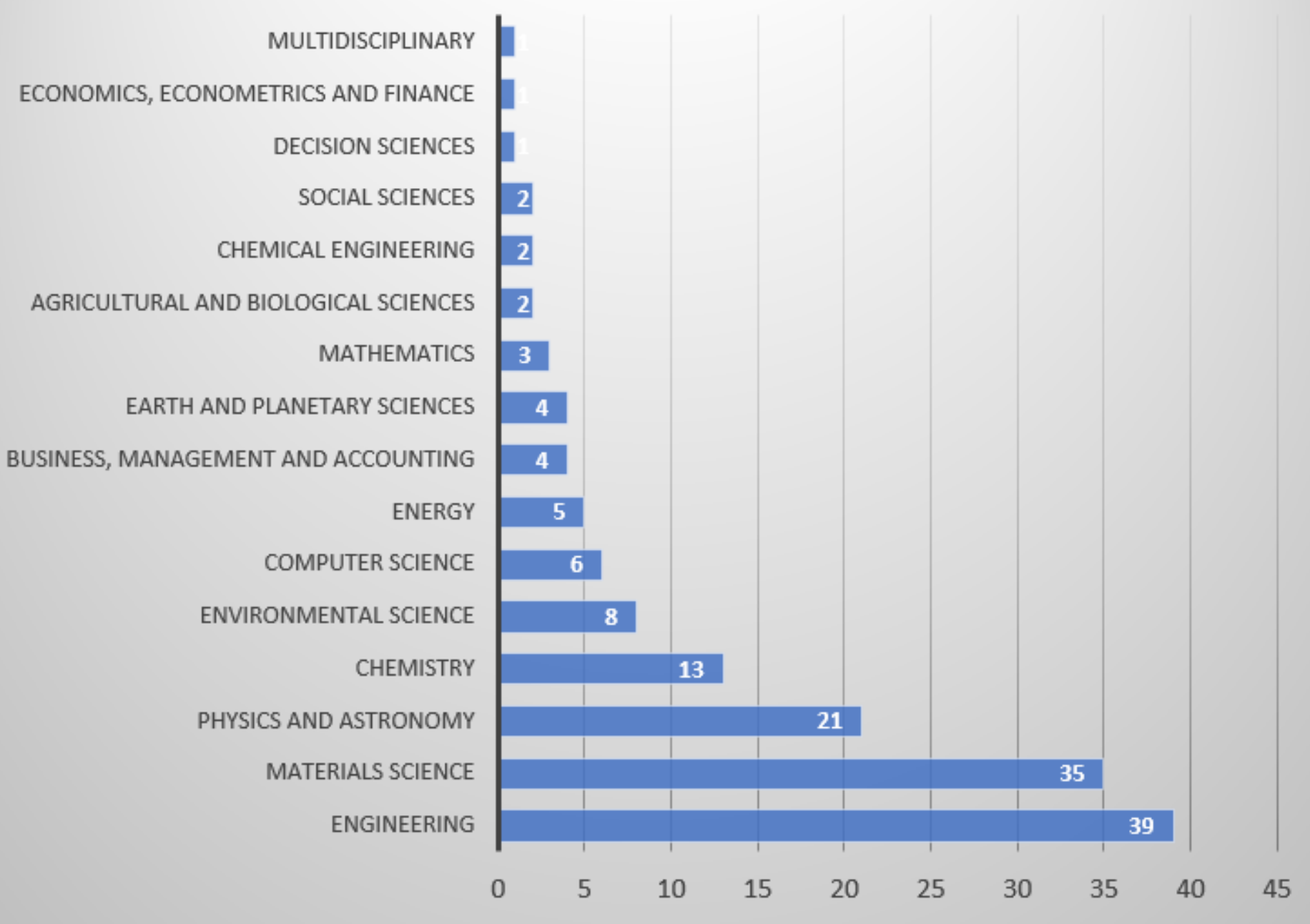

\section{Figure 8}

Distribution, by subject area, of Brazilian articles containing the words aggregates, residues and concrete in the title or in the keywords or in the abstract, in the base Scopus 


\section{Brazilian articles on thematic area Environmental Science in the Scopus database}

\section{5}

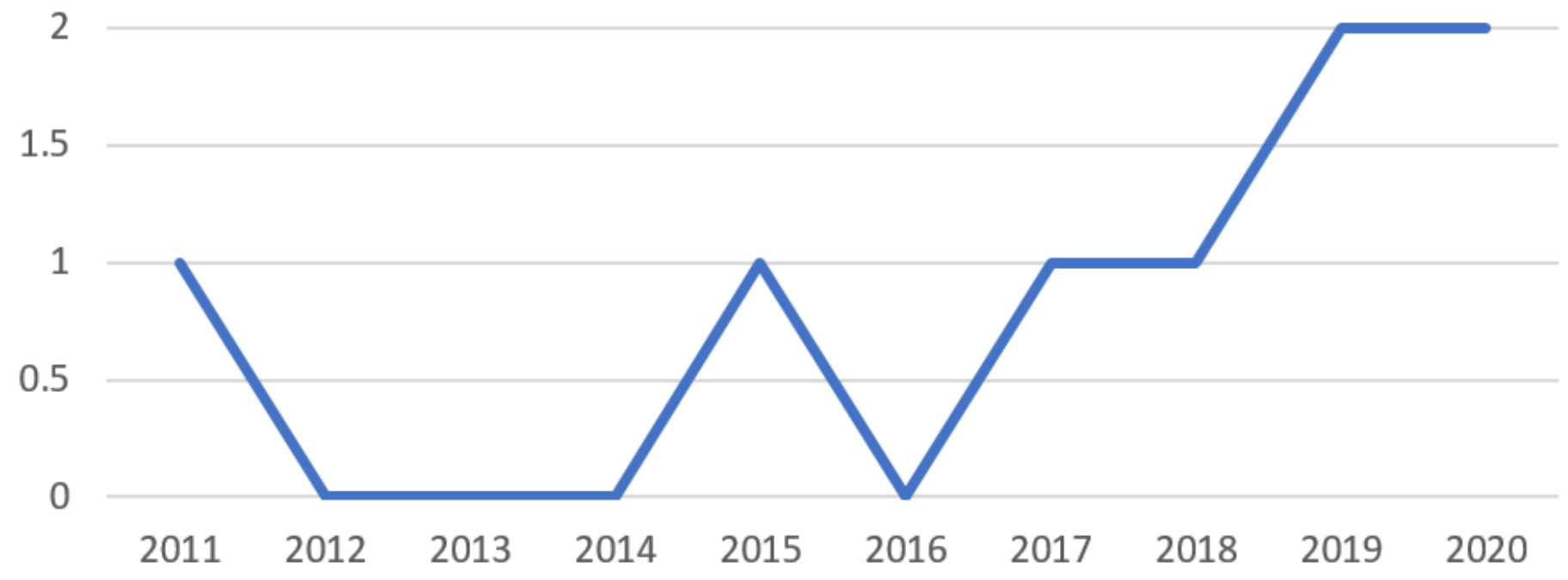

\section{Figure 9}

Yearly distribution of Brazilian articles on thematic area Environmental Science in the Scopus database 


\section{Main information of articles with Brazilian}

\section{authors in the Scopus database}

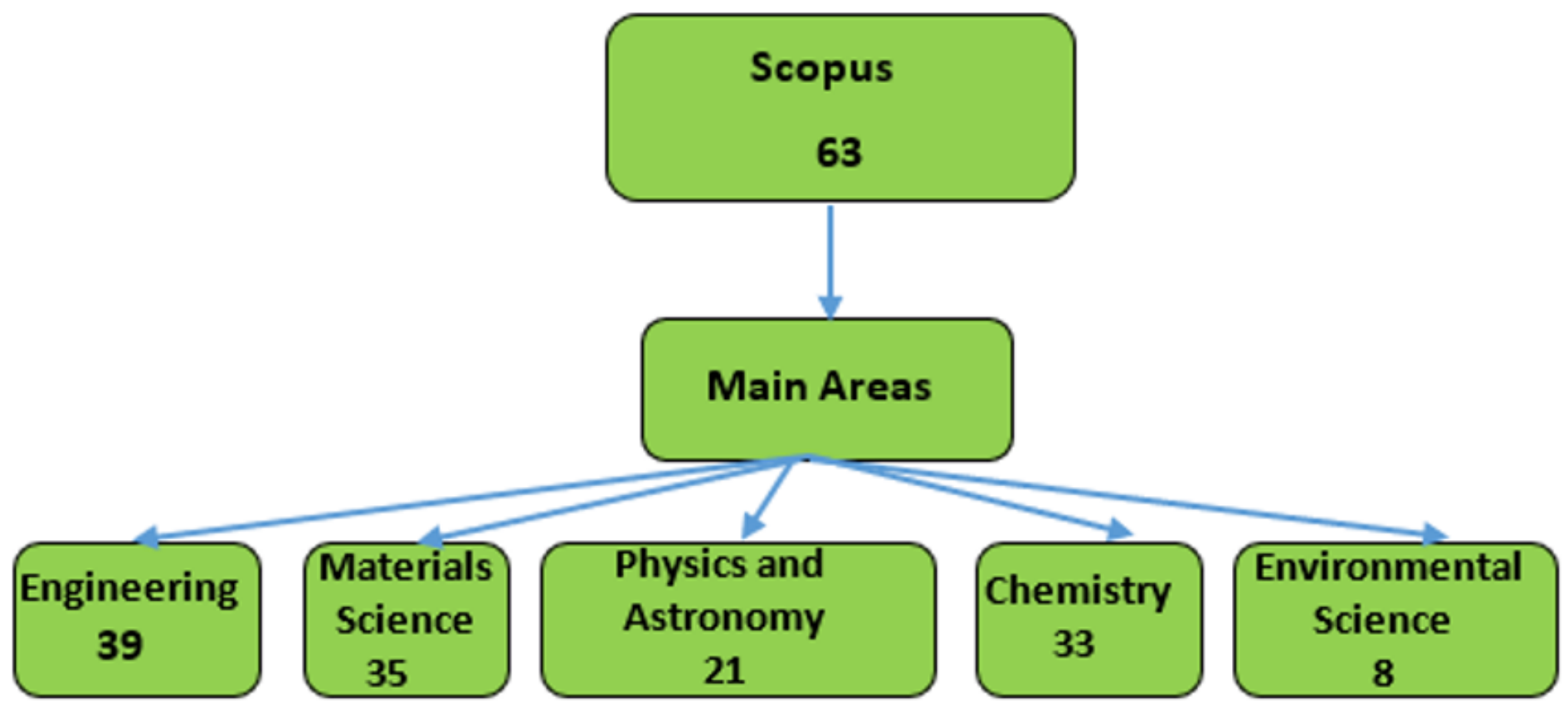

Figure 10

Summary of the main information obtained in the Scopus base of articles with Brazilian authors with the words aggregates, residues and concrete in the title, abstract or keywords

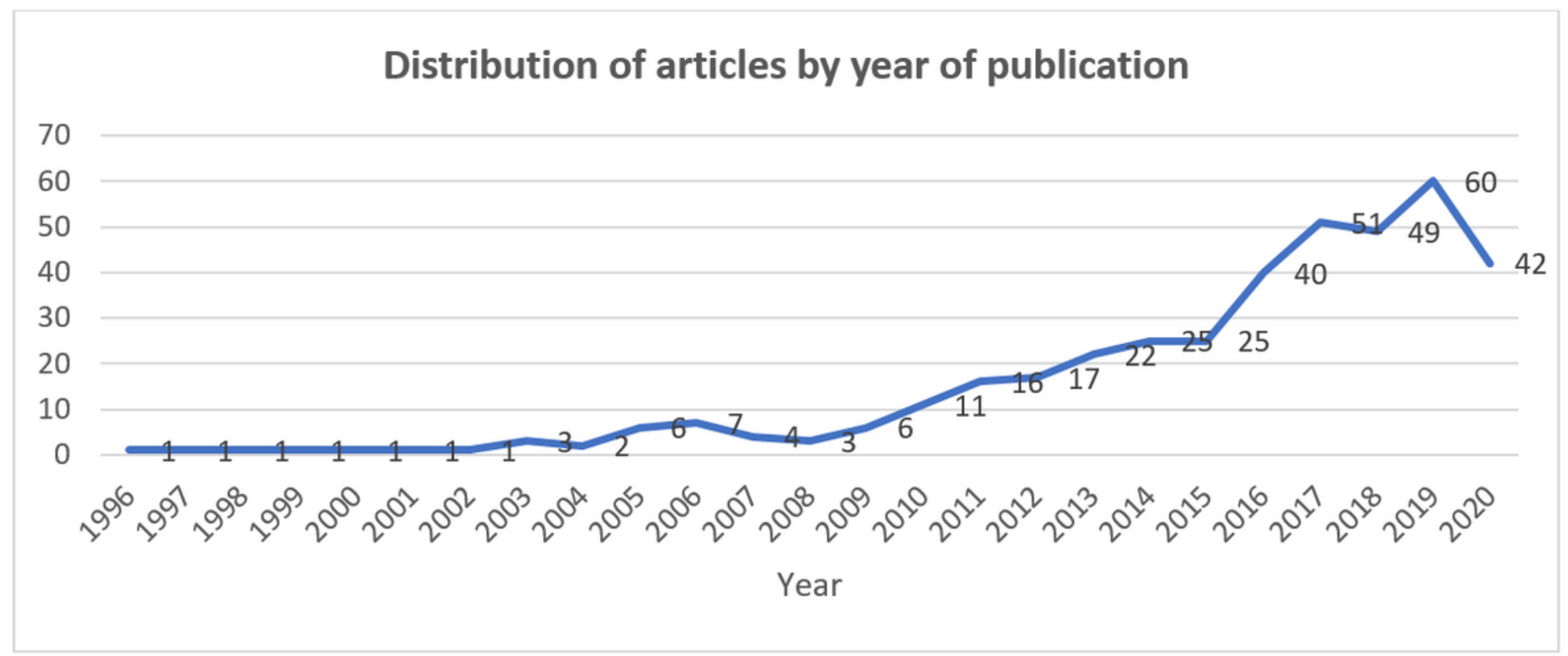

Figure 11 
Articles with the words aggregates, residues and concrete in the title or keywords or abstract of the Web of Sciences database

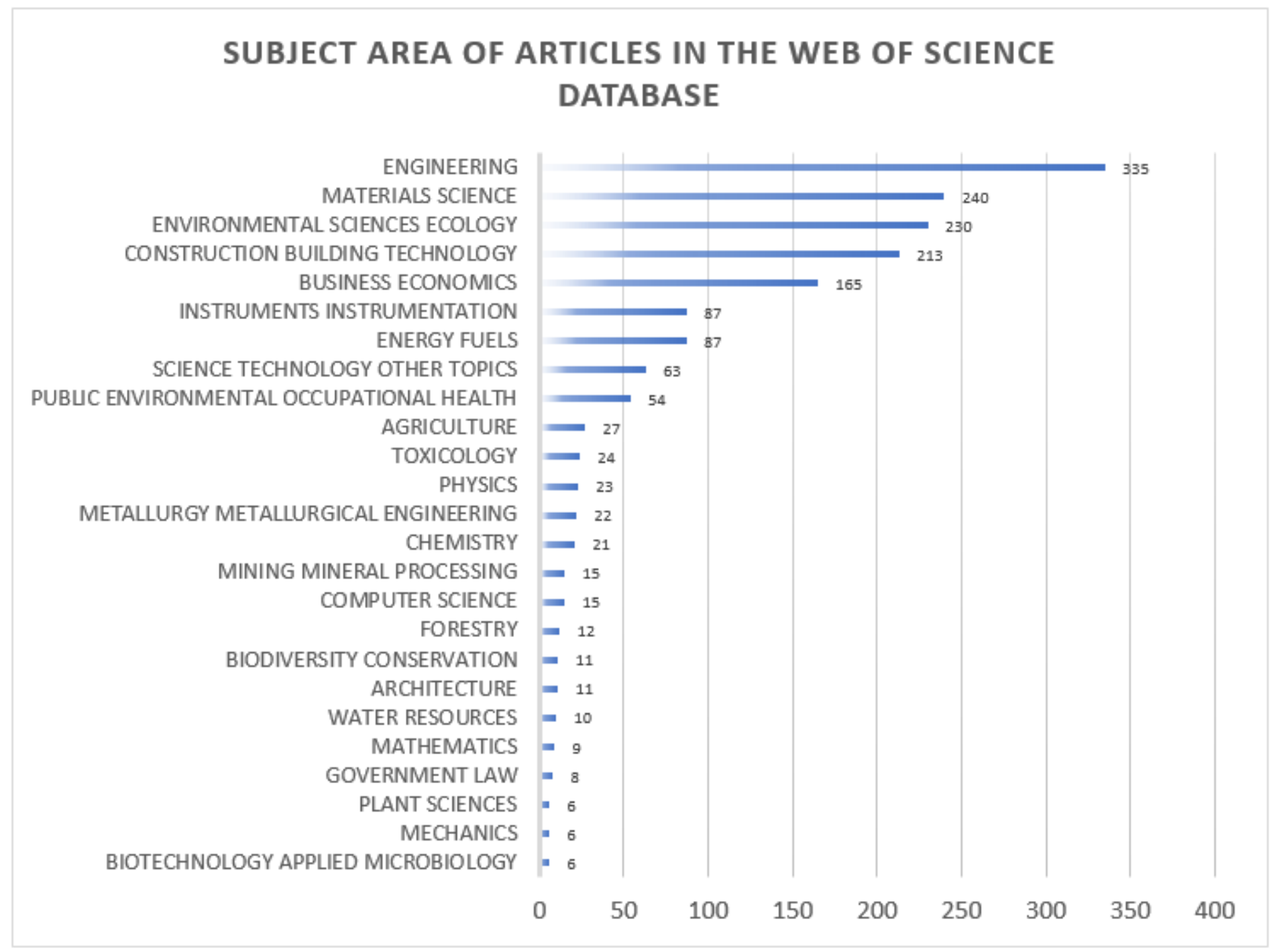

\section{Figure 12}

Distribution, by subject area, of articles with the words aggregates, residues and concrete in the title or keywords of the Web of Sciences database 


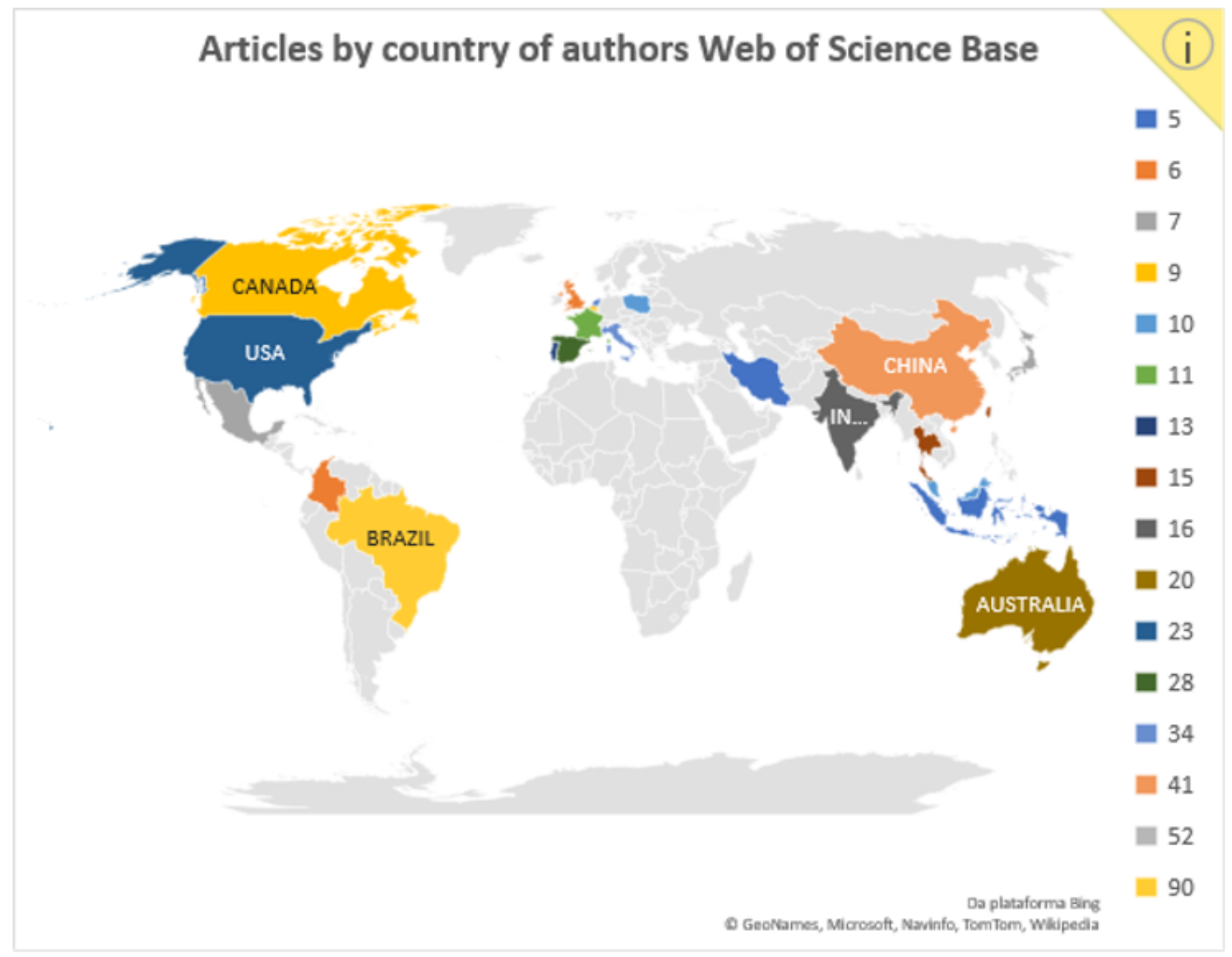

\section{Figure 13}

Distribution, by country, of the 401 articles containing the words aggregates, residues and concrete in the title or in the keywords or in the abstract. Note: The designations employed and the presentation of the material on this map do not imply the expression of any opinion whatsoever on the part of Research Square concerning the legal status of any country, territory, city or area or of its authorities, or concerning the delimitation of its frontiers or boundaries. This map has been provided by the authors. 


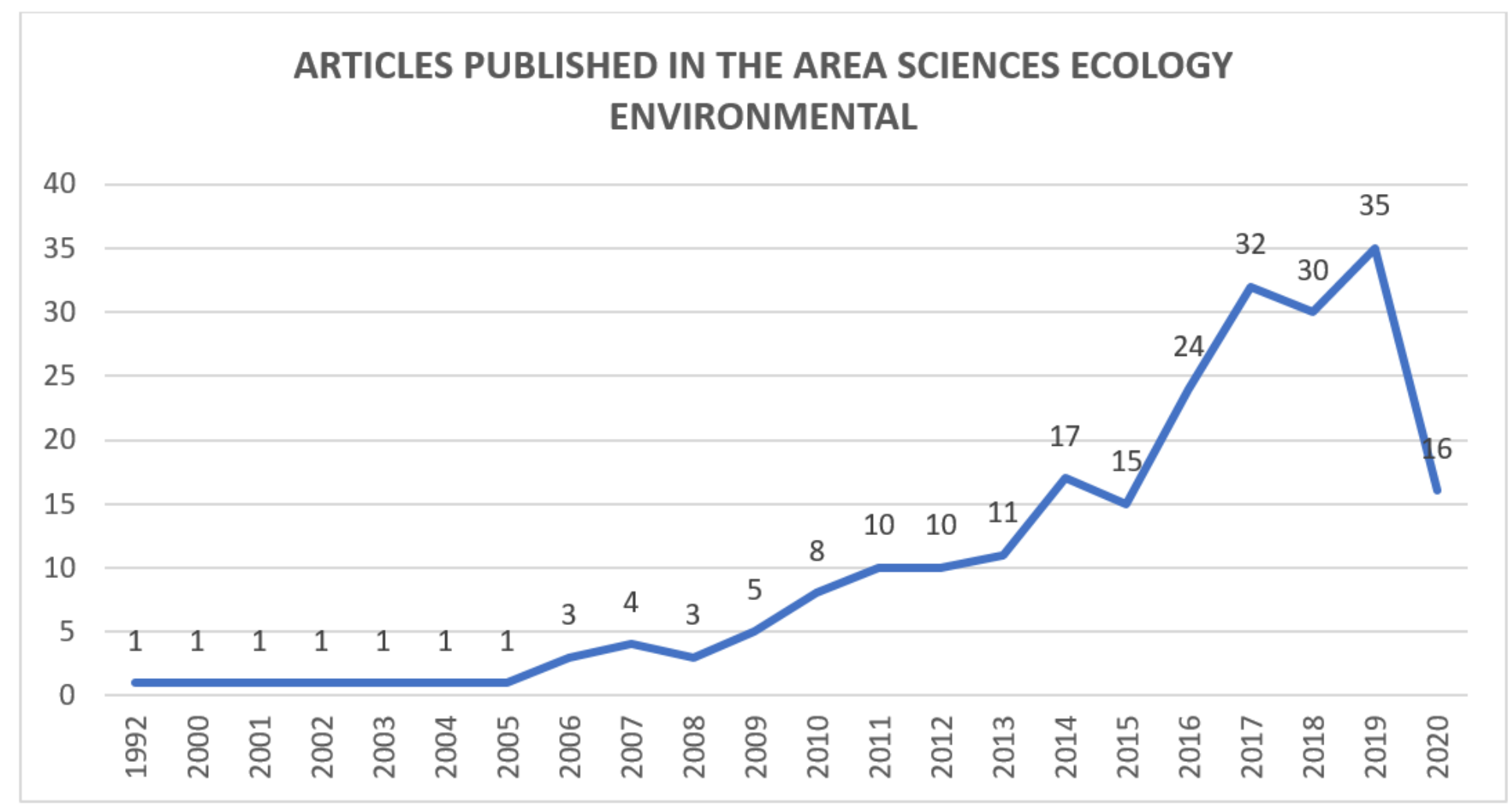

Figure 14

Distribution, by year of publication, of articles in the Sciences Ecology Environmental area, on the Web of Science database 


\section{Articles by country of authors Web of Science Base}

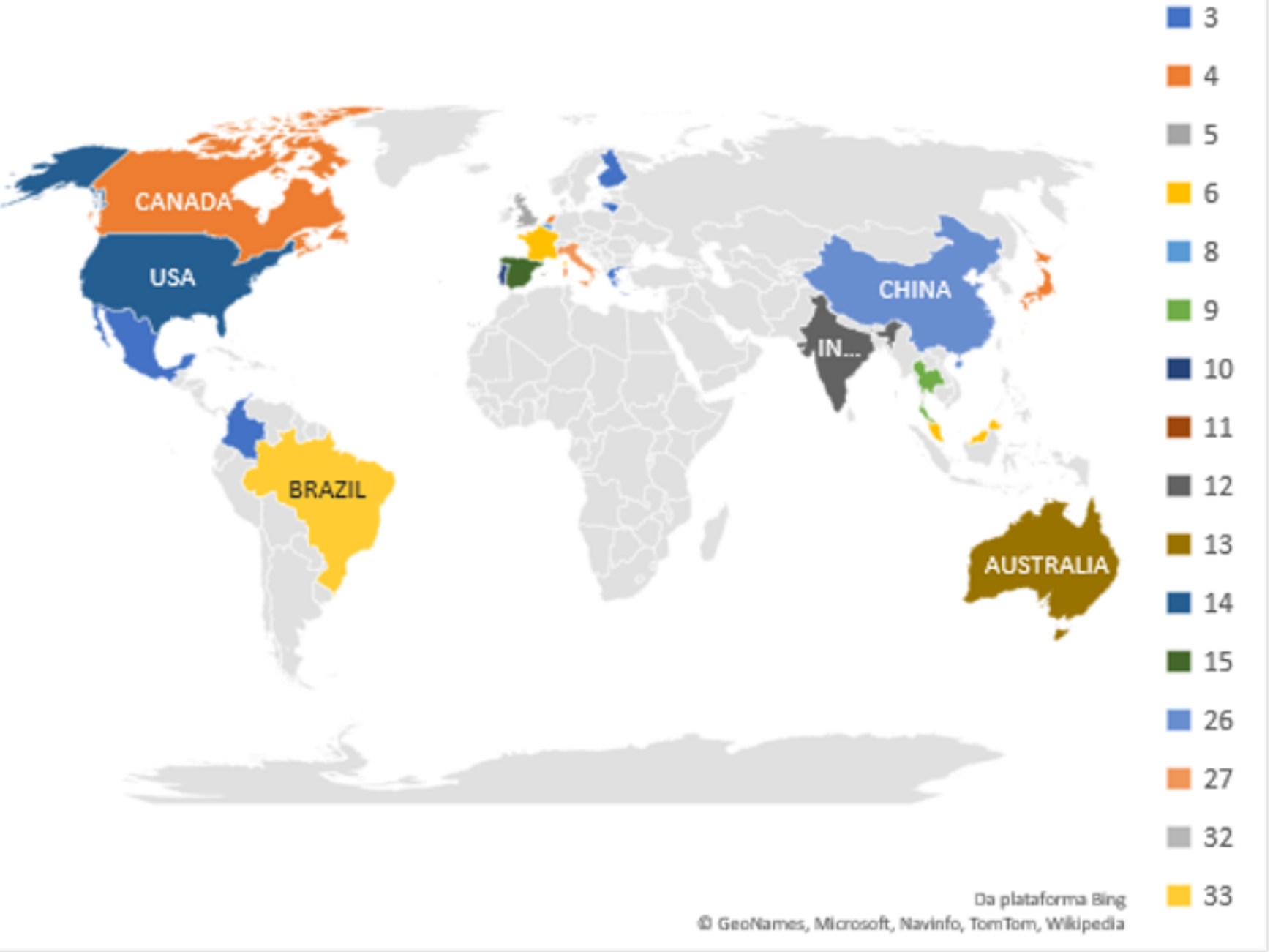

\section{Figure 15}

The 230 articles in the subject area Environmental Sciences Ecology, containing the words aggregates, residues and concrete in the title or in the keywords or in the abstract in the Web of Sciences base. Note: The designations employed and the presentation of the material on this map do not imply the expression of any opinion whatsoever on the part of Research Square concerning the legal status of any country, territory, city or area or of its authorities, or concerning the delimitation of its frontiers or boundaries. This map has been provided by the authors. 


\section{Main information in the Web of Sciences database}

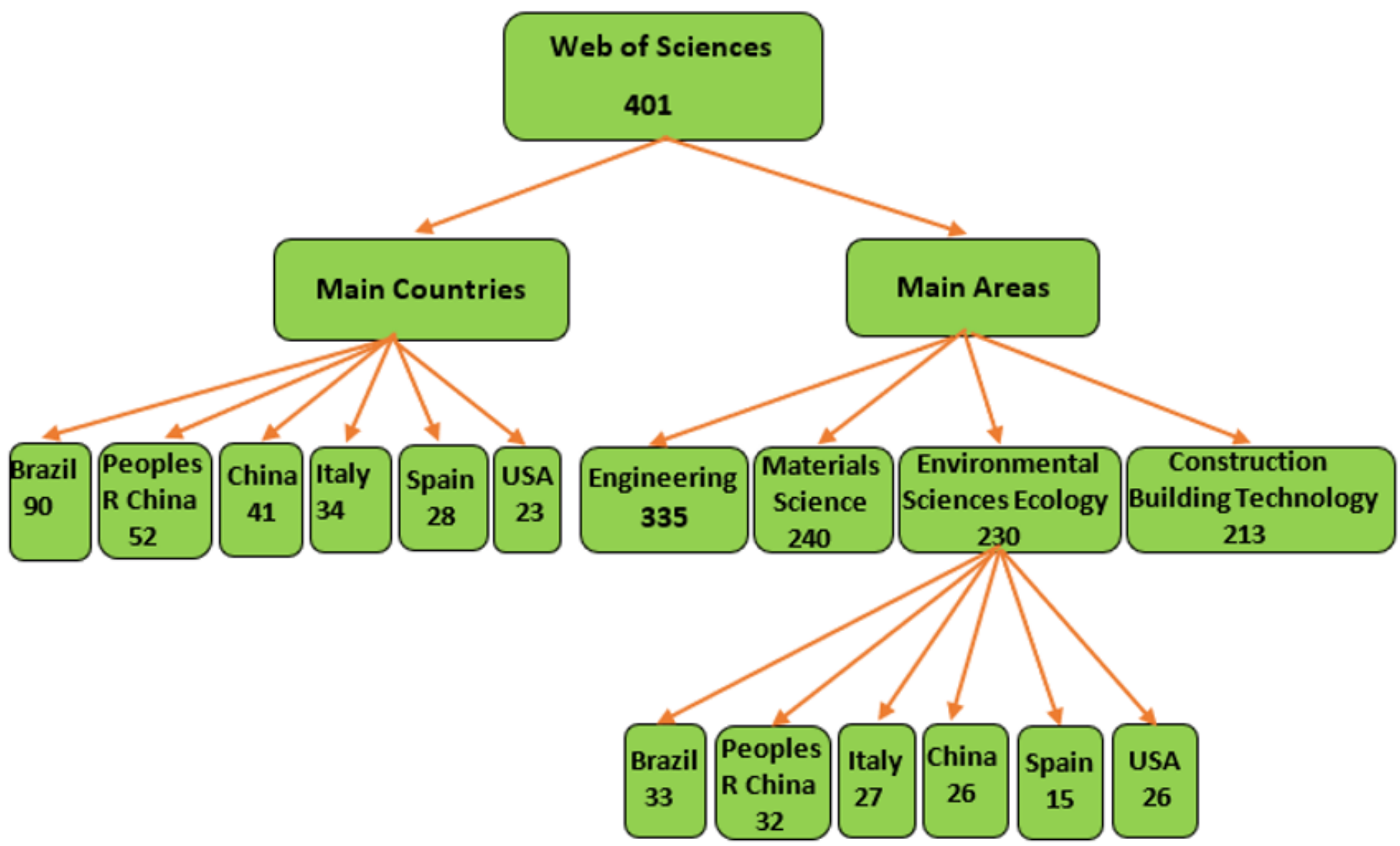

Figure 16

Summary of the main information obtained in the Web of Sciences base of articles with the words aggregates, residues and concrete in the title, abstract or keywords 


\section{Subject area of articles in the Web of Sciences database of the brazilian articles}

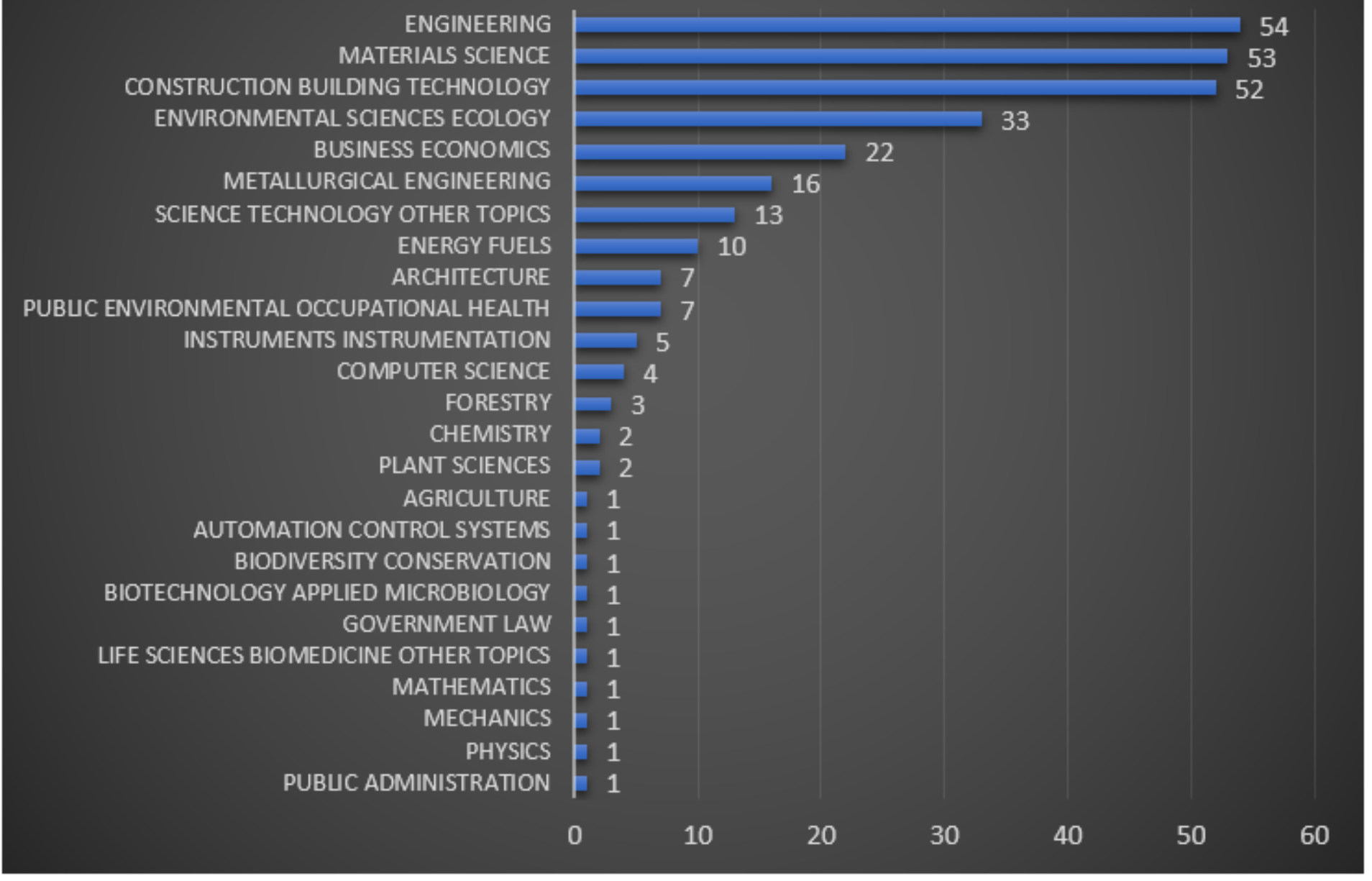

\section{Figure 17}

Distribution, by subject area, of the Brazilian articles in the Web of Sciences database. 


\section{DISTRIBUTION OF ARTICLES BY YEAR OF PUBLICATION}

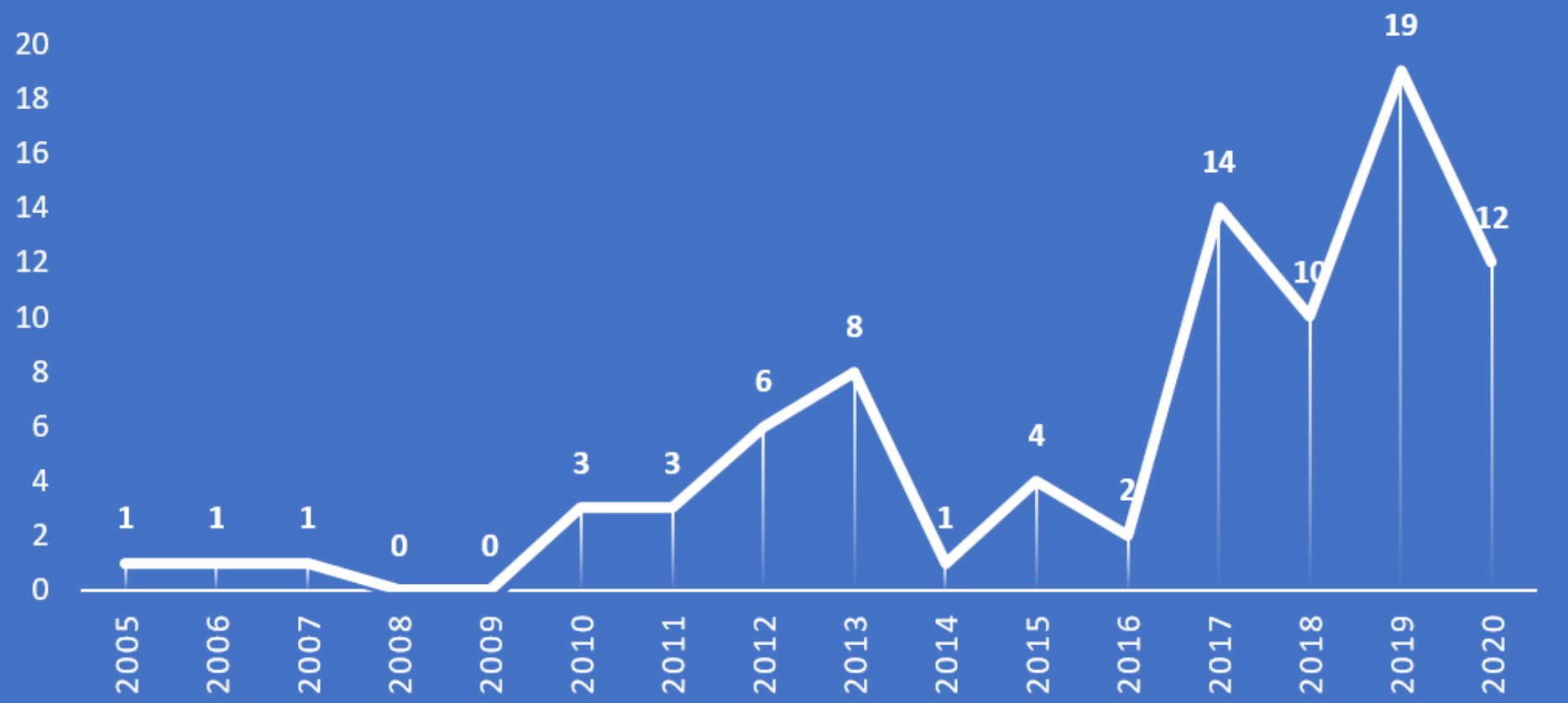

\section{Figure 18}

Distribution, by year of publication, of the articles by Brazilian authors, on the Web of Sciences database.

\section{BRAZILIAN ARTICLES IN THE SUBJECT AREA SCIENCES ECOLOGY ENVIRONMENTAL ON THE WEB OF SCIENCES DATABASE}

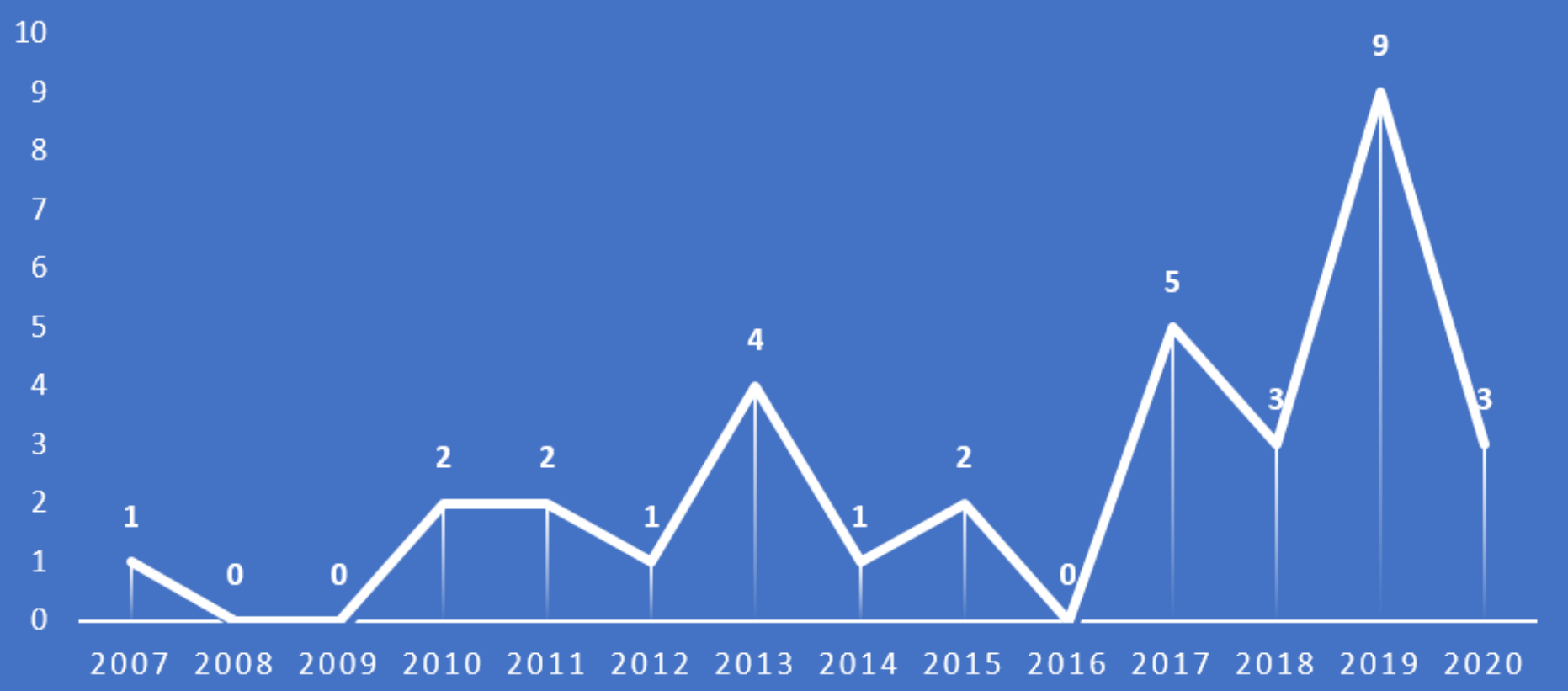


Figure 19

Distribution, by year of publication, brazilian articles in the subject area Sciences Ecology Environmental on the Web of Sciences database

\section{Main information of articles with Brazilian}

\section{authors in the Web of Sciences database}

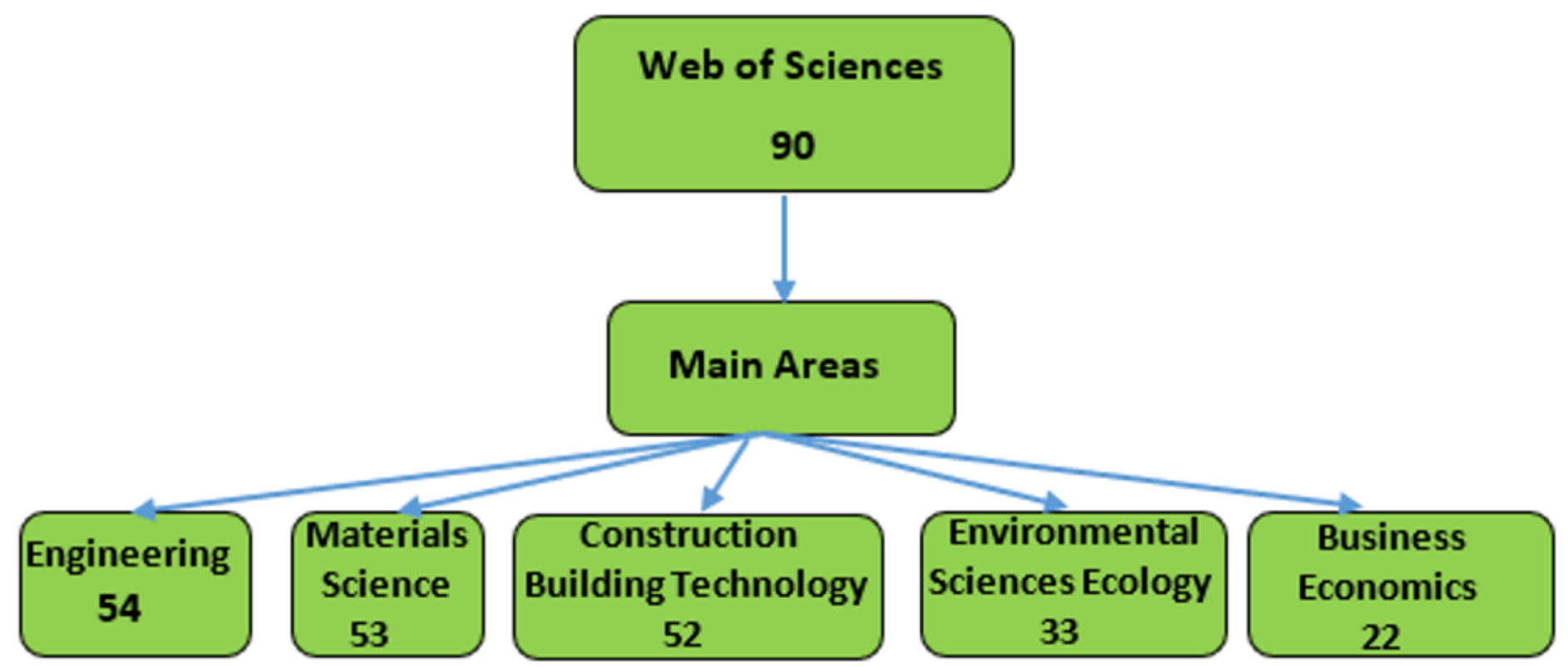

Figure 20

Summary of the main information obtained in the Web of Sciences base of articles with Brazilian authors with the words aggregates, residues and concrete in the title, abstract or keywords 